\title{
Bagasse Ash as an Auxiliary Additive to Lime Stabilization of an Expansive Soil: Strength and Microstructural Investigation
}

\author{
Jijo James $\mathbb{D}^{1}$ and P. Kasinatha Pandian ${ }^{2}$ \\ ${ }^{1}$ SSN College of Engineering, Rajiv Gandhi Salai, Kalavakkam, Tamil Nadu 603110, India \\ ${ }^{2}$ Karpaga Vinayaga College of Engineering and Technology, Chinnakolambakkam, Padalam, Kanchipuram 603308, India \\ Correspondence should be addressed to Jijo James; jijothegreat@gmail.com
}

Received 19 August 2017; Revised 30 January 2018; Accepted 19 February 2018; Published 2 May 2018

Academic Editor: Hossein Moayedi

Copyright ( 2018 Jijo James and P. Kasinatha Pandian. This is an open access article distributed under the Creative Commons Attribution License, which permits unrestricted use, distribution, and reproduction in any medium, provided the original work is properly cited.

\begin{abstract}
The study dealt with the effect of addition of sugarcane bagasse ash (BA) on the strength development of a lime stabilized expansive soil. Unlike previous investigations with combinations of lime and BA, this study compares the effect of lime contents determined by scientifically established procedures and the effect of BA on the stabilization of lime at different proportions with additional microstructural investigations. The minimum lime content required for stabilization known as initial consumption of lime (ICL) was determined using the Eades and Grim pH test as 5.5\%. The optimum lime content (OLC) was determined using unconfined compression strength (UCS) tests as 7\%. Another lime content less than ICL was randomly adopted as 3\%. The three lime contents were mixed with $0.25 \%, 0.5 \%, 1 \%$, and $2 \%$ BA. UCS samples of dimension $38 \mathrm{~mm} \times 76 \mathrm{~mm}$ were prepared at a fixed dry density and moisture content and cured for periods of 2 hours (0 days), 3, 7, 14, and 28 days to study the development of strength and effect of BA. Mineralogical and microstructural analyses were performed on the pulverized UCS samples after failure. The results revealed that the addition of BA increased the immediate, early, and delayed strength of lime stabilized soil further, even when the lime content was lower than ICL. Addition of BA produced maximum immediate, early, and delayed strength gains of $58.3 \%, 20.7 \%$, and $32.7 \%$, respectively. Higher proportion of BA was required when lime content was above ICL, for maximum strength. Addition of BA resulted in better utilization of quartz in lime-soil reactions leading to formation of CSH and CAH minerals. A dense compact matrix was seen on analyzing the microstructure of the stabilized soil composite.
\end{abstract}

\section{Introduction}

Lime stabilization is one of the most commonly adopted techniques for stabilization of expansive soils that have always posed problems to civil and geotechnical engineers all over the world. However, in recent times, the focus is on the utilization of industrial waste materials along with lime in order to achieve improved performance and waste management. There is extensive literature in utilization of industrial wastes in combination with lime for beneficial effects in lime stabilization [1-8]. Similarly, this study envisages to investigate the effect of sugarcane bagasse ash (BA), one of the many industrial wastes produced in India, on the strength of a lime stabilized expansive soil. Bagasse is the fibrous residue remaining after the extraction of the cane juice from sugarcane. In sugarcane industries, bagasse is used as fuel resulting in its combustion and production of ash as the end product. This waste is typically disposed into pits and also used as soil amendment in some areas [9]. Earlier work on BA involves its utilization as replacement in concrete $[10,11]$, compressed stabilized earth blocks [6, 12-14], and sintered blocks/tiles [15-17] apart from soil stabilization. The utilization of BA in soil stabilization has been increasing in recent years. Muazu studied the plasticity and particle size distribution [18] and effect of compaction [19] on BA amended cement-treated lateritic soil. Chittaranjan et al. [20] explored the effect of BA on the CBR value of stabilized soil. Onyelowe [21] investigated the effect of BA as an admixture to cement stabilization of lateritic soil. Sabat [22] evaluated the performance of expansive soil stabilized using combinations of lime sludge and BA. Osinubi et al. [23] looked into the compatibility of stabilization of lateritic soil with BA and 


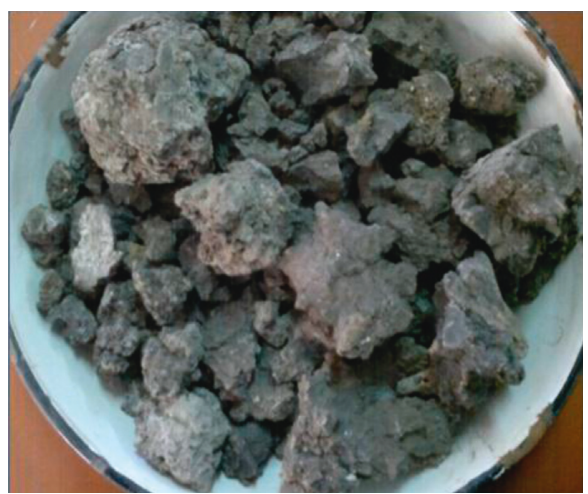

(a)

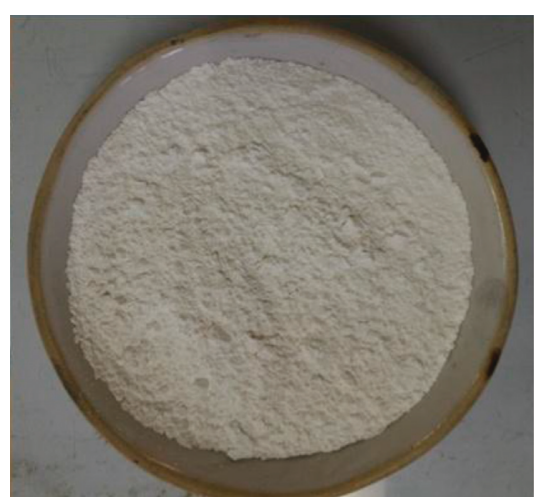

(b)

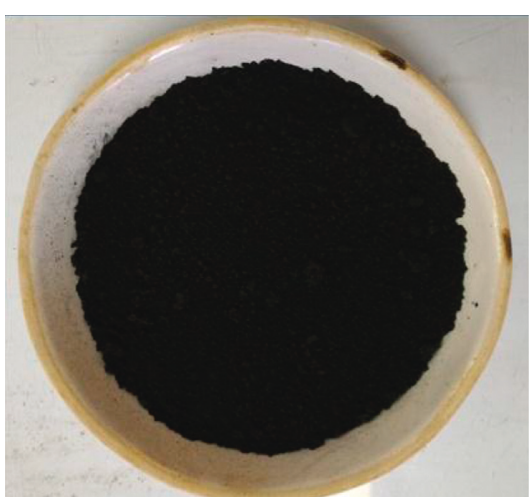

(c)

FIgUre 1: Materials adopted in the study: (a) soil, (b) lime, and (c) BA.

TABle 1: Properties of soil.

\begin{tabular}{|c|c|c|c|c|c|c|c|c|c|}
\hline$w_{\mathrm{L}}(\%)$ & $w_{\mathrm{P}}(\%)$ & $I_{\mathrm{p}}(\%)$ & $w_{\mathrm{S}}(\%)$ & $G_{\mathrm{s}}$ & $\gamma_{\mathrm{dmax}}\left(\mathrm{kN} / \mathrm{m}^{3}\right)$ & $w_{\text {opt }}(\%)$ & UCS $(\mathrm{kPa})$ & $\mathrm{pH}$ & FSI (\%) \\
\hline 68 & 27 & 41 & 10 & 2.76 & 15.3 & 25 & 115.8 & 6.53 & $98 \%$ \\
\hline \multicolumn{2}{|c|}{$\%$ gravel } & \multicolumn{2}{|c|}{$\%$ sand } & \multicolumn{2}{|r|}{$\%$ silt } & & $\%$ clay & Classification & $\begin{array}{l}\text { cation } \\
y\end{array}$ \\
\hline
\end{tabular}

municipal solid waste leachate. Osinube and Thomas [24] studied influence of compaction on BA-treated black cotton soil. Ali et al. [25] investigated the effects of combination of marble dust and BA in stabilization of an expansive soil. Osinubi et al. [26] examined the strength and CBR of lime stabilized soil with BA. Manigandan and Moganraj [8] evaluated the consolidation characteristics of lime stabilized soil with BA. Sadeeq et al. [27] explored the effect of BA on lime stabilized lateritic soil. Dang et al. [28, 29] studied the strength and mechanical behaviour of lime and BA treated expansive soil. Hasan et al. [30] investigated the strength property of expansive soils treated with lime and BA and the effect of wetting and drying cycles on the durability of the stabilized soil. Jamsawang et al. [31] looked into the potential of BA waste as a replacement for cement in stabilization of soft clay. Lime stabilization has been and still is one of the preferred methods of soil stabilization for expansive soils. The concepts of Initial Consumption of Lime (ICL) and Optimum Lime Content (OLC) have been well established through several literature works. However, in studies on combinations of lime with pozzolans, very few researchers have adopted the scientifically established concepts of ICL and OLC for stabilization. It is also observed that researchers still adopt trial and error method for identifying lime contents for use in soil stabilization with pozzolans. It was also noticed that investigators adopted either ICL or OLC while working on lime stabilization of soils with pozzolans. Very few investigations have been carried out on the comparison of the effects of these two scientifically established lime contents. Considering the case of stabilization with lime-pozzolan (like BA), work details are further limited. In fact, the majority of such limepozzolan-based studies adopted combinations on a trial and error basis [32]. Hence, a detailed investigation on the performance of lime stabilized soil amended with BA was necessitated. Thus, an experimental study was devised to study the strength and index properties of an expansive soil treated with lime and BA with mineralogical and microstructural studies. This study, however, deals only with the strength characteristics of lime treated expansive soil amended with BA along with mineralogical and microstructural studies.

\section{Materials}

The materials adopted in this study are the natural soil, lime used for stabilization, and BA used as admixture and are shown in Figure 1. The natural soil was obtained from Thatthamanji village located in Thiruvallur district, Tamil $\mathrm{Nadu}$, India. Its geotechnical properties are tabulated in Table 1. The lime used for the investigation was laboratorygrade hydrated lime $\left[\mathrm{Ca}(\mathrm{OH})_{2}\right]$ manufactured by Nice Chemicals India Pvt. Ltd. Laboratory-grade lime was used as available out of the bottle without any preparation. BA used in this study was sourced from Thirutthani Sugar Mills Pvt. Ltd. in Arakkonam district of Tamil Nadu, India. The chemical composition of materials used in the study is tabulated in Table 2.

Scanning electron microscopy (SEM) images were used to study the morphology of the materials. Figure 2 shows the structure of the materials adopted in the study from SEM. The micrograph reveals that soil particles are aggregated into lumps due to cohesive nature of the clayey soil. However, it also shows the platy clay particles that make up the soil aggregates. Lime possesses very fine-grained particles when compared to the other waste materials. It can also be seen that the lime particles are also aggregated into larger lumps. The microstructure of BA showed well-defined burnt flakes of bagasse. The field of view shows the charred cellular 
TABLE 2: Chemical composition of materials.

\begin{tabular}{lccccccccccc}
\hline & $\mathrm{SiO}_{2}(\%)$ & $\mathrm{Al}_{2} \mathrm{O}_{3}(\%)$ & $\mathrm{CaO}(\%)$ & $\mathrm{Fe}_{2} \mathrm{O}_{3}(\%)$ & $\mathrm{K}_{2} \mathrm{O}(\%)$ & $\mathrm{MgO}(\%)$ & $\left.\mathrm{MnO}^{2} \%\right)$ & $\mathrm{Na}_{2} \mathrm{O}(\%)$ & $\mathrm{P}_{2} \mathrm{O}_{5}(\%)$ & $\mathrm{TiO}_{2}(\%)$ & $\mathrm{SO}_{3}(\%)$ \\
\hline Soil & 63.62 & 18.82 & 2.30 & 7.48 & 2.29 & 1.74 & 0.04 & 1.42 & 0.04 & 0.88 & 0.20 \\
Lime & 0.25 & 0.05 & 72.77 & 0.04 & 0.003 & 14.60 & 0.004 & 0.05 & 0.005 & 0.003 & 0.05 \\
$\mathrm{BA}$ & 35.17 & 0.281 & 2.07 & 5.22 & 3.75 & 0.91 & 0.04 & 0.01 & 1.03 & 0.02 & 0.03 \\
\hline
\end{tabular}

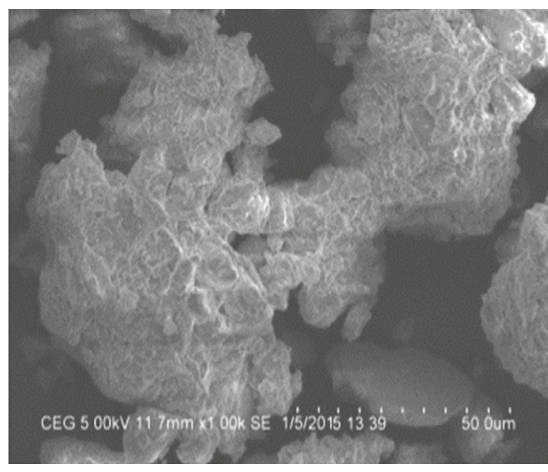

(a)

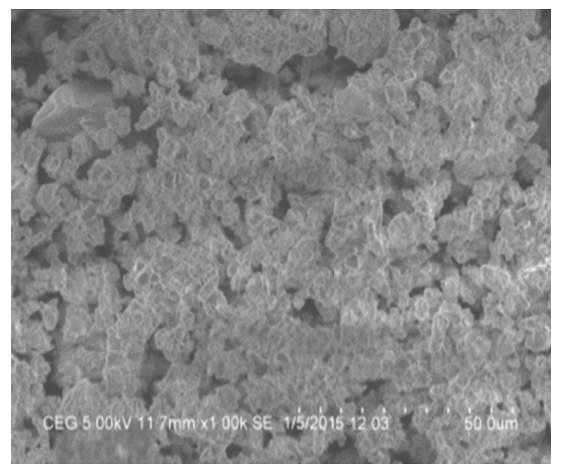

(b)

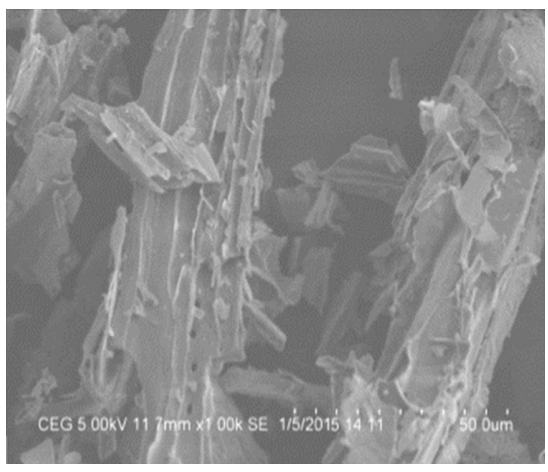

(c)

Figure 2: SEM micrograph of the materials adopted in the study: (a) soil, (b) lime, and (c) BA.

structure of bagasse preserved due to the high temperature of burning; however, there is a slight collapse of structure due to the fragile nature of the burnt flakes. However, BA consists of both crystalline bulky grains and pyrolyzed organic fractions [17]. Figure 3 shows the XRD patterns of the material used. A basic analysis of the XRD patterns was performed with Crystal Impact Match! Software Version 3.0.3 and Crystallography Open Database for reference patterns. Mineralogical analysis of soil from Figure 3 indicates the presence of montmorillonite and quartz. The identification of montmorillonite can be done by the presence of a peak at location of $14 \AA$ [33]. Other peak location indicators of the mineral include $4.49 \AA, 9.0 \AA$, and $18.0 \AA$ [34]. The d-spacing of $4.49 \AA$ corresponds to a 2 -theta value of $19.78^{\circ}$. On close observation of the scatter pattern of the soil sample, a peak corresponding to this location was noticed. This was also reported by Kalkan [35]. The 2-theta values corresponding to the other $\mathrm{d}$-spacings do not fall within the available range of the test performed. A peak at 2-theta value of $28^{\circ}\left[35\right.$ ] and $36^{\circ}$ [36] also indicates the presence of montmorillonite mineral. Similar peaks were also found in the scatter pattern of the soil under study confirming the presence of the mineral. Quartz can be identified at d-spacings of $1.15 \AA, 1.18 \AA, 1.37 \AA, 1.82 \AA$, and $3.34 \AA$ [37]. Similarly, peaks corresponding to the above locations were also found in the present soil. The diffractogram of lime revealed the presence of calcium hydroxide. A minor peak of calcite was also noticed. Similar peaks were also reported by Kampala and Horpibulsuk [38] and Solanki and Zaman [39]. The mineralogical characterization of BA shed light on the presence of cristobalite (low), quartz, and calcium carbonate/calcite. Cristobalite (low) is meta-stable, whereas cristobalite (high) is unstable at low temperatures. Others have reported the presence of quartz, cristobalite, calcite, calcium phosphate, mullite, iron oxide, and microcline among others [31, 40-44].

\section{Methods}

The geotechnical properties of the soil were determined in the laboratory in accordance with BIS specifications which included liquid and plastic limit [45], shrinkage limit [46], specific gravity [47], grain size distribution [48], compaction characteristics [49], unconfined compressive strength (UCS) [50], and $\mathrm{pH}$ [51], followed by classification [52] of the soil. Following the characterization of various materials used in the investigation, the quantity of lime required for improving the soil properties was determined. Nasrizar et al. [53] state that there are three phases in the relationship between strength and lime content in lime stabilization of soils, namely, below ICL, between ICL and OLC, and above OLC. Based on this, three different lime contents were adopted for soil modification in this investigation, namely, ICL, OLC, and one value less than ICL (LICL). The ICL value was determined from the Eades and Grim pH test in accordance with ASTM code [54] while OLC was determined based on procedure described by Thompson [55]. The same procedure was also adopted by others in their investigations [56-58]. A random value of lime content below ICL was selected for the investigation.

Following the determination of the lime contents, four additive dosages were selected at random, namely, $0.25 \%$, $0.5 \%, 1 \%$, and $2 \%$. The experimental investigation began with determination of the altered compaction characteristics of lime stabilized soil. Compaction tests were performed on soil stabilized with different lime contents in a Jodhpur mini compactor apparatus based on the procedure laid down by Singh and Punmia [59]. Each trial in the Jodhpur Compaction test was done with a fresh batch of soil mixed with the required quantity of lime by weight with the quantity of water alone increasing with each subsequent trial in accordance with BIS [60]. The optimum moisture content and 


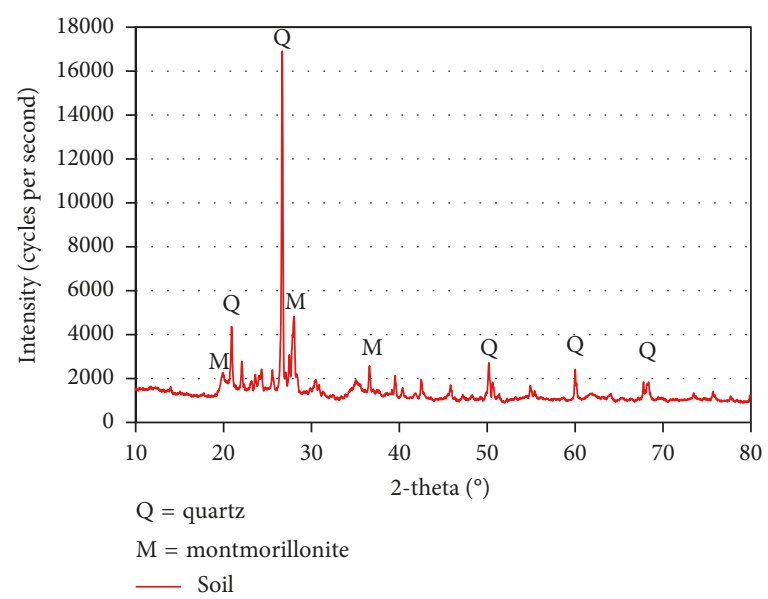

(a)

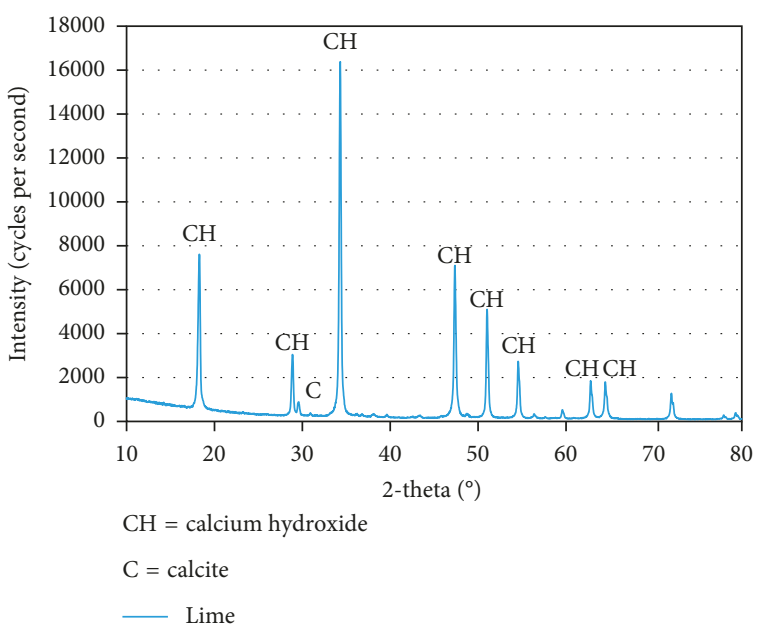

(b)

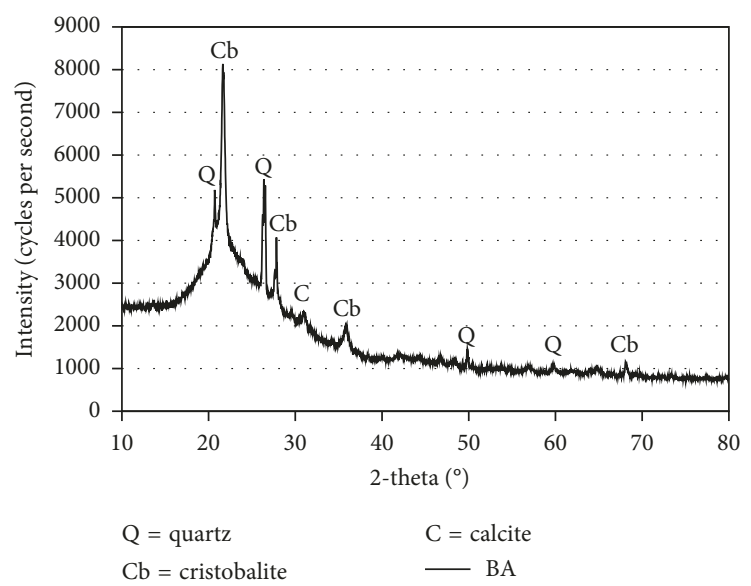

(c)

Figure 3: X-ray diffractograms of (a) soil, (b) lime, and (c) BA.

maximum dry density determined from the Jodhpur mini compaction test are close to the values obtained by the Standard Proctor compaction test within the close limits of experimental error [59]. The Jodhpur compaction tests were performed only for the three lime contents adopted for stabilization. One value of moisture content and dry density was selected out of the three sets of values obtained and set as the dry density and moisture content for preparation of all UCS test samples. A similar procedure was also adopted by Wild et al. [1] and Bagheri et al. [61]. Basically, all samples had the same density and moisture content within the limits of experimental error. In the present investigation, all samples were prepared to a target dry density of $14.72 \mathrm{kN} / \mathrm{m}^{3}$, at $25 \%$ water content. The UCS samples were prepared in a constant volume split mould of dimensions $38 \mathrm{~mm} \times 76 \mathrm{~mm}$. Measured quantities of soil, lime, and BA, calculated to achieve the target dry density, were taken in a pan and was mixed by hand in dry conditions. The required quantity of water based on the specified water content was sprinkled over the mix and was thoroughly and uniformly mixed to achieve a wet mix. The UCS mould was prepared by lubricating its interior surface with oil, and one end was plugged using an end plug. The wet mix was then packed in the UCS mould in layers with gentle pressure provided using the compaction plug to ensure a good packing of the mix. This was repeated until the entire measured mix was packed into the mould. Another end plug was used to plug the top, and it was statically compacted using a universal sample compactor cum extruder. It was ensured that while packing the mould, the mix was alternatively introduced from either end and compacted statically from the corresponding end [62]. This enabled a uniformly compacted UCS specimen and reduced the possibilities of loose pockets in the specimen. The sample was then demoulded by splitting open the mould and providing a gentle push using the compaction plug from one end of the specimen. The samples were immediately placed inside a sealable polythene cover for curing. Three samples were prepared for testing each of the combinations. The samples were cured at a room temperature of $30 \pm 2^{\circ} \mathrm{C}$, for periods of 2 hours, $3,7,14$, and 28 days for determination of strength of the stabilized soil. At the end of the set periods of curing, the samples were removed from their sealed polythene covers and loaded axially until failure at 


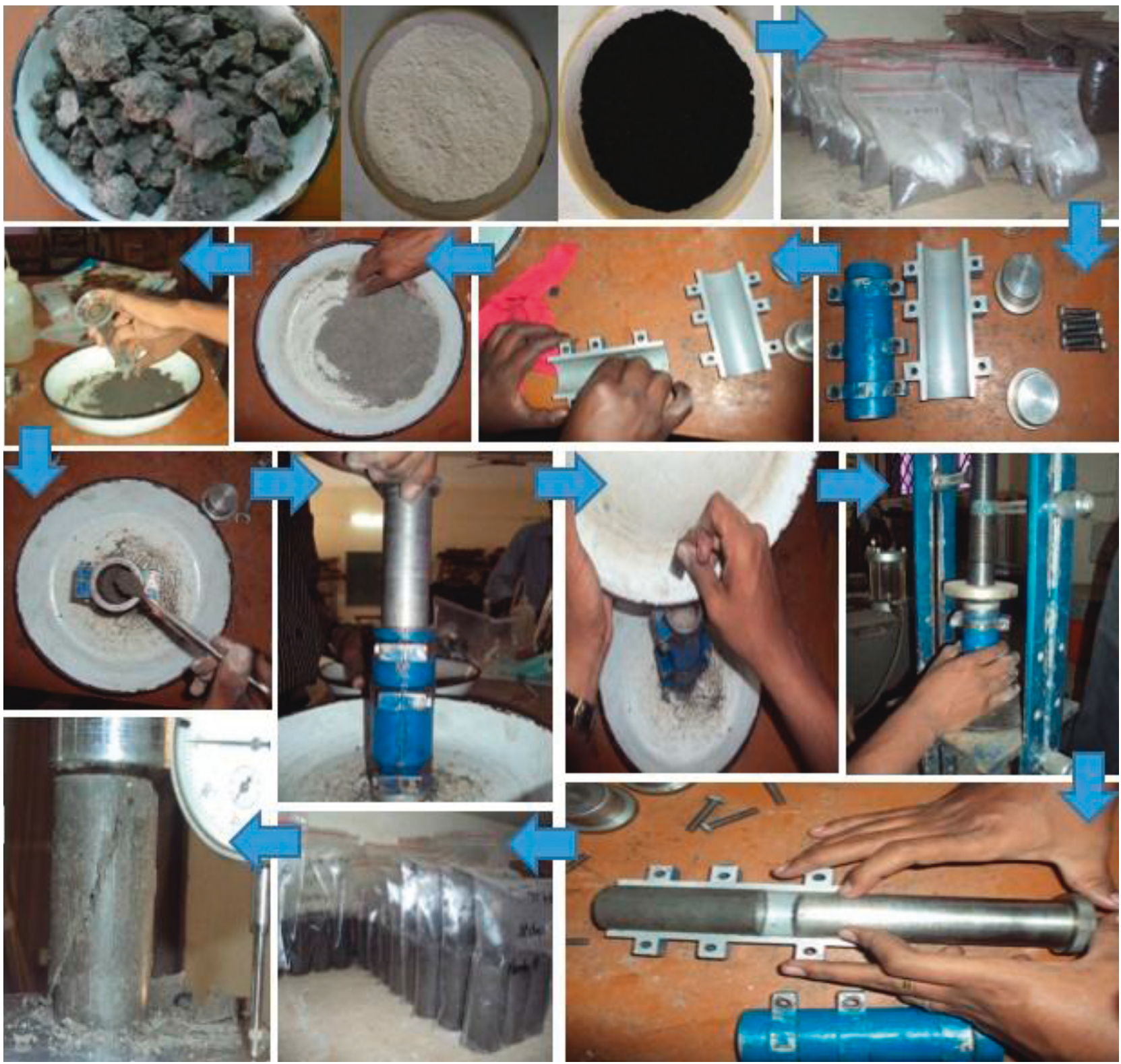

Figure 4: Preparation of UCS sample.

a strain rate of $0.625 \mathrm{~mm} / \mathrm{min}$. The tested samples were then crushed, pulverized, dried, and sieved for mineralogical analysis. Fractured pieces of the test specimen were also sent for microstructural analysis. XRD was performed in a benchtop diffractometer model Rigaku Miniflex 2C. X-rays of wavelength of $1.54 \AA$ was adopted with continuous mode Gonio scan between 2-theta positions of $10^{\circ}$ and $90^{\circ}$ with a scan step of $0.02^{\circ}$ and a scan speed of $25^{\circ} /$ minute. A current of $10 \mathrm{~mA}$ and a voltage of $30 \mathrm{kV}$ were set in the generator. Figure 4 shows the preparation of test specimens for strength tests.

\section{Results and Discussion}

The ICL indicates the minimum amount of lime needed to achieve a $\mathrm{pH}$ of 12.4 and bring about prominent changes to soil properties, plasticity, and compaction in particular, along with activation of pozzolanic reactions [63]. Based on the experimental investigation, ICL was fixed as $5.5 \%$ and OLC as $7 \%$, and LICL was randomly taken as $3 \%$.

4.1. Effect of BA Quantum on the Uniaxial Strength. The influence of BA on the UCS of lime stabilized expansive soil at various curing periods is displayed in Figure 5. It is evident that addition of BA increases the strength of lime stabilized soil irrespective of lime content adopted for stabilization. When $3 \%$ lime content was amended with $0.25 \% \mathrm{BA}$, the strength of the soil increased by $23.7 \%$ to $677.25 \mathrm{kPa}$. Similarly, for $5.5 \%$ lime stabilization, the strength increased even further by $32.7 \%$ to $1856.39 \mathrm{kPa}$. When $7 \%$ lime content was amended with $0.5 \% \mathrm{BA}$, a strength gain of $17.5 \%$ was 


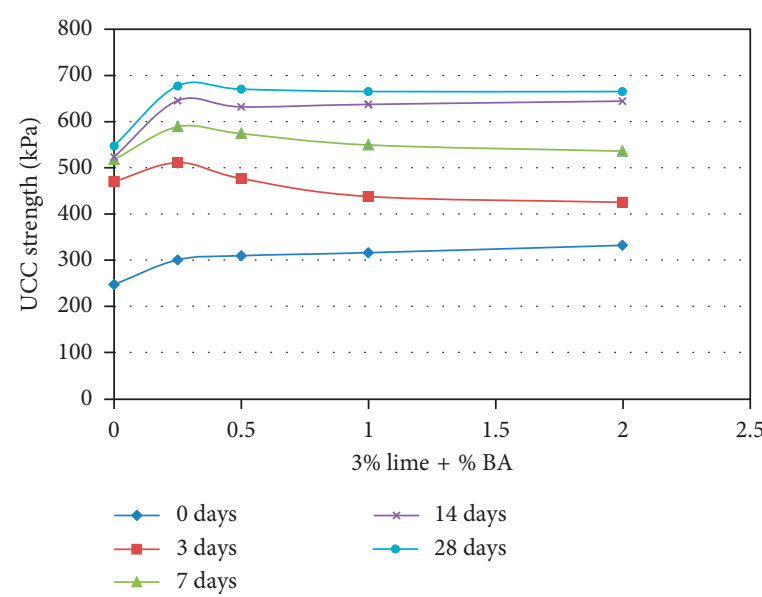

(a)

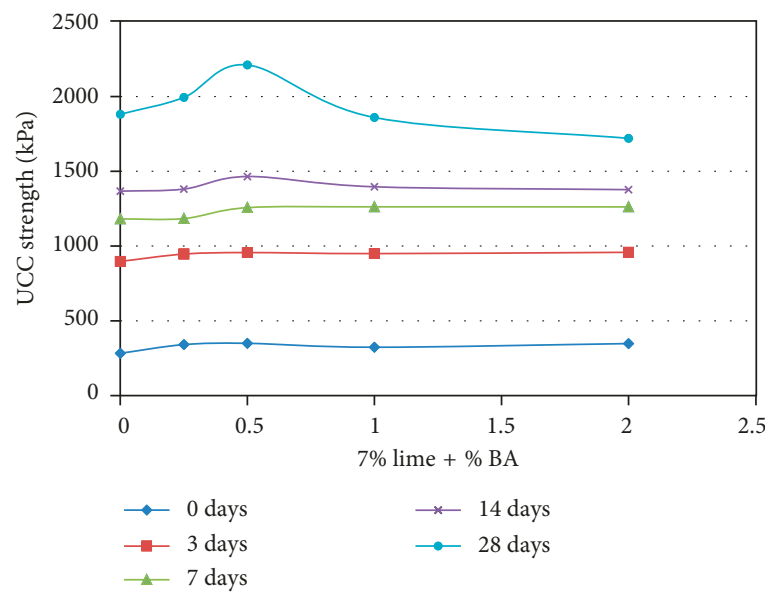

(c)

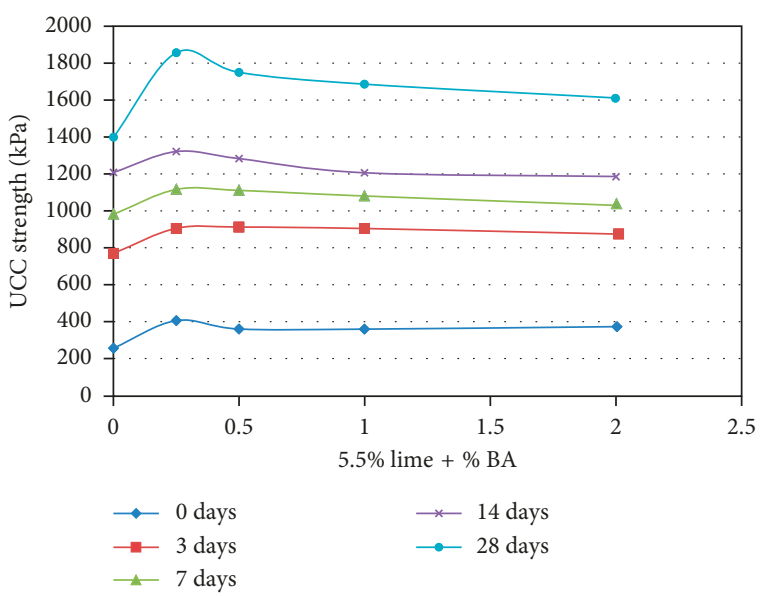

(b)

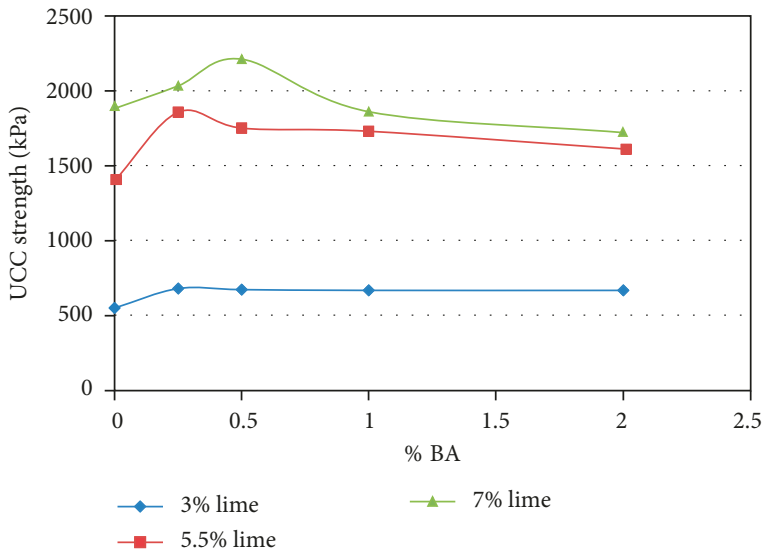

(d)

FIgURE 5: Variation of UCS with \% BA for lime stabilized soil: (a) 3\%, (b) 5.5\%, (c) 7\%, and (d) 28-day UCS comparison.

obtained, raising the strength to $2211.11 \mathrm{kPa}$. All three lime contents when amended with BA have produced gain in strength after 28 days of curing with at least two combinations of BA. A similar result has been reported in the investigations of earlier researchers with an increase in strength when combinations of lime and BA were used [27-30]. The increase in strength of the stabilized soil due to addition of BA can be attributed to chemical reactions taking place in the form of cation exchange, pozzolanic reaction, and cementation. Dang et al. [29] stated that the flocculation and agglomeration of soil due to stabilization results in the soil resisting compressive stress effectively than virgin expansive soil. The pozzolanic reactions take place between calcium from lime and silica and alumina from soil and BA in the presence of water to form cementitious compounds $\mathrm{CSH}$ and $\mathrm{CAH}$ which result in enhanced strength of the stabilized composite $[6,27,64,65]$.

Another major inference is that when the lime content is higher than ICL, there is an increase in BA content that produces maximum strength of the stabilized soil. This, however, cannot be seen below ICL wherein the optimal dose of BA remains the same. James and Pandian [58] found a similar trend wherein more PG was required to achieve high strength with high lime content in soil stabilization. In similar terms, it can be stated that more BA gets involved in the pozzolanic reactions when more lime is available for stabilization. A similar trend was also noticed in the work done by Hasan et al. [30] with combinations of lime and BA. However, for lime content at and below ICL, similar optimal BA content may be due to the limitation of the test programme of not having any trial BA content below $0.25 \%$.

It may be noticed that for LICL and ICL stabilized soil, all combinations of BA produced positive strength addition. But at higher OLC stabilization, only two out of the four BA contents resulted in strength improvement. In terms of utilization, BA seems to be more effective in bringing about positive strength benefits at lower doses of lime content when compared to higher lime content. The absolute increase in strength may be higher at higher lime content; however, the quantum of gain is better at lower lime contents of ICL and LICL when compared to OLC. It can be postulated that BA amendment of lime stabilization is effective at lower lime contents, particularly close to ICL rather than OLC. James et al. [13] reported that BA was more effective in enhancing the strength of cement stabilized soil blocks at lower cement content when compared to higher 
cement content. Similar effects were also found in the other works analyzed $[12,66]$ as a part of the work done by James et al. [13].

Looking at earlier work done, Sadeeq et al. [27] adopted combinations of lime and BA for stabilization of lateritic soil but the UCS of the optimal combination of lime $(8 \%)$ and BA $(6 \%)$ was below $1000 \mathrm{kPa}$, whereas in the present study, the addition of BA to lime stabilization of an expansive soil resulted in strength in excess of $2000 \mathrm{kPa}$. Sabat [22] adopted a combination of lime sludge and BA to increase the strength of an expansive soil. The optimal combination of $16 \%$ lime sludge and $8 \%$ BA almost doubled the UCS of the soil; however, a strength of $120 \mathrm{kPa}$ of the stabilized soil was very low in comparison with the present study which may be due to the use of lime sludge instead of lime whose calcium content is lesser than lab grade lime. Osinube and Thomas [24] found that combinations of $8 \%$ cement and $4 \%$ BA produced significant improvement in soil strength but still did not meet the criteria of $1710 \mathrm{kPa}$ strength for use as base materials suggested by TRRL. Earlier work cited adopted trial and error combinations of lime and BA, and the strengths reported were low. In the present work, the approach for determining ICL and OLC for stabilization in combination with BA resulted in significant strength of the expansive soil.

4.2. Effect of Curing on Strength of Lime-BA Stabilized Soil. Figure 6 shows the effect of curing on the development of strength of BA admixed lime stabilized soil. The graph reveals the development of strength of optimal BA content admixed lime stabilized soil. It can be clearly seen that provision of curing significantly influences the strength development of BA amended lime stabilized soil. In fact, BA amended lime stabilized soil develops strength more rapidly in comparison to pure lime stabilized soil. Similar results were reported by Hasan et al. [30] as well as Dang et al. [29]. It can be inferred that the most significant gain in strength of stabilized soil takes place when ICL content is admixed with $0.25 \%$ BA. However, BA is capable of raising the strength of the lime stabilized soil at all three contents. At LICL content, it can be seen that the gain in strength is below par at early curing of 3 days; however, beyond seven days of curing, the strength gain is more or less stable. At 7 days of curing, the strength gain is $13 \%$ whilst it is $23.7 \%$ at 28 days of curing which is almost a one-fourth gain in strength. Although BA addition increases the strength of the soil stabilized at LICL content, the strength curve becomes asymptotic before 28 days of curing, indicating that the lime is used up for shortterm reactions rather than pozzolanic reactions [67] and, hence, BA complements the short-term reactions of lime resulting in the strength gain seen at this stage of lime stabilization. At ICL content, the strength gain is $21 \%$ at 3 days and $13 \%$ at 7 days. However, the greatest gain is achieved at 28 days of curing at $32.7 \%$. This is almost a onethird gain in strength. At OLC content, the addition of BA results in a comparatively lesser gain in strength though the absolute strength values are higher. The strength gain hovers around $7 \%$ till 14 days of curing and then jumps to gain

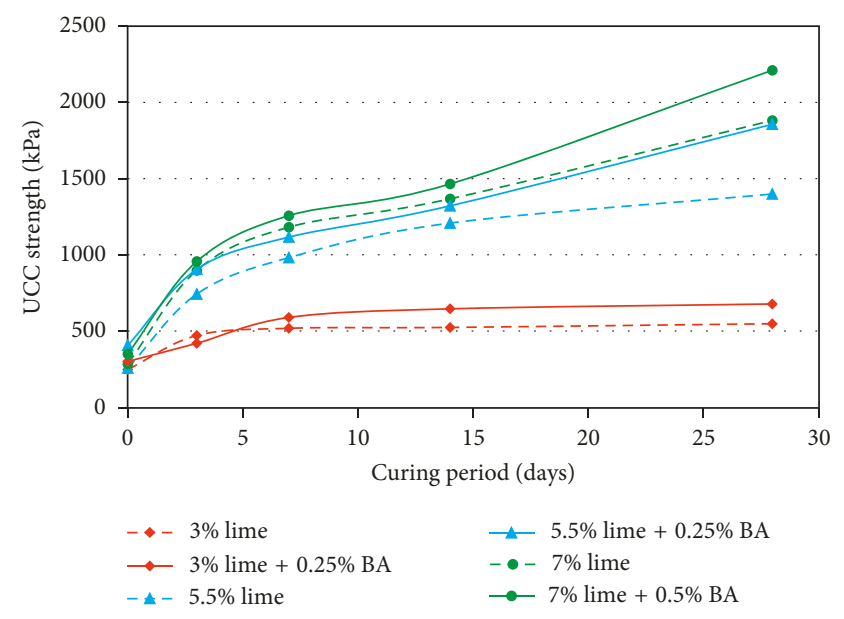

FIGURE 6: Comparison of UCS with curing period of lime stabilized soil with and without BA.

$17.5 \%$ at 28 days of curing. It is clear that lime content below ICL does not have a significant impact on the strength gain despite BA addition augmenting it slightly. A similar result was also reported by Dang et al. [29] wherein they state a low threshold of lime has little impact on the strength gain of expansive soil. This may be due to insufficient lime available to supply calcium ions for pozzolanic reactions to continue over a longer period of time. It can also be noticed that the strength development of 5.5\% lime stabilized soil admixed with $0.25 \% \mathrm{BA}$ almost touches the strength developed by $7 \%$ lime stabilized soil at 28 days of curing. Thus, BA addition can result in similar strength at lower lime content. Hasan et al. [30] stated that the presence of BA accelerates the cementitious reactions between lime and soil. In an earlier work done by James and Pandian [58], PG could not achieve such a similar effect of producing similar strength at low lime content. There was a noticeable difference between the strength of $5.5 \%$ lime stabilized soil with PG and $7 \%$ lime stabilized soil. Osinubi et al. [26] had reported that combinations of $8 \%$ lime with $4 \%$ BA did not achieve a 7 -day evaluative strength criteria of $1034.25 \mathrm{kPa}$, whereas in the present study, ICL with $0.25 \% \mathrm{BA}$ and OLC with $0.5 \% \mathrm{BA}$ developed higher strengths of $1115.88 \mathrm{kPa}$ and $1256.76 \mathrm{kPa}$, respectively.

4.3. Percentage Strength Gain. A percentage strength gain analysis was performed from the point of view of additive proportions and curing period. The percentage strength gain analysis was done by comparing the strength of pure lime stabilized soil with that of additive dosed lime stabilized soil at corresponding curing periods. This enables to understand the development of strength in percentage for different additive dosages. Three curing periods were specifically chosen for the analysis, namely, 0 days, 7 days, and 28 days. The strength developed corresponding to these three curing periods were designated "Immediate Strength," "Early Strength," and "Delayed Strength," respectively. The term "Late Strength" was not adopted for 28 days of curing because the development of strength continues for weeks or 


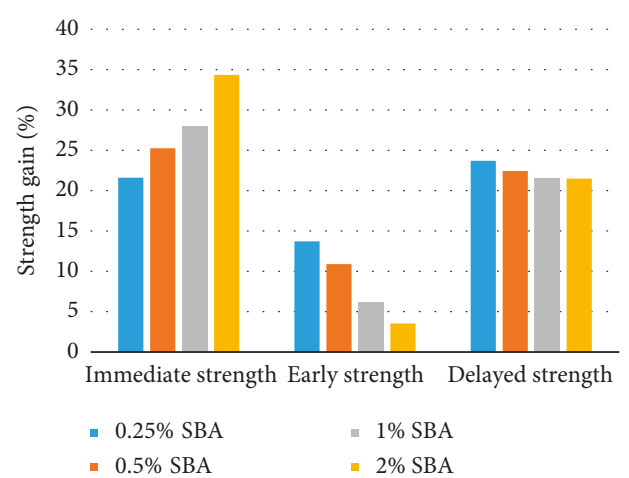

(a)

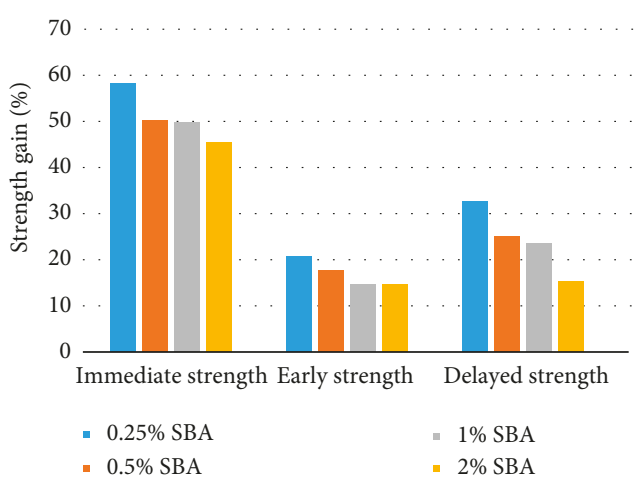

(b)

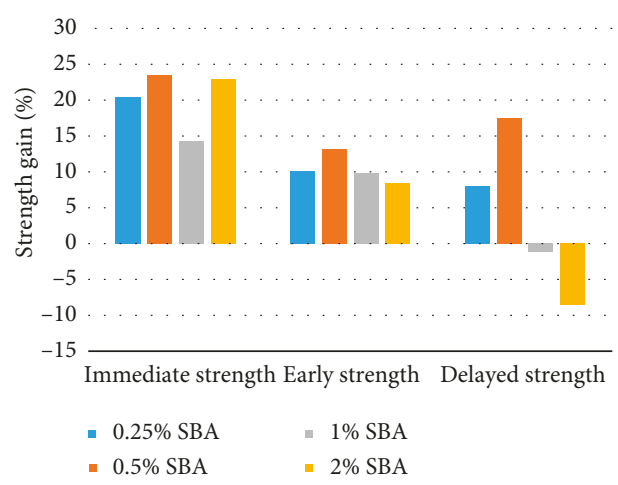

(c)

FIGURE 7: Percentage strength gain of (a) 3\%, (b) 5.5\%, and (c) 7\% lime stabilized soil with BA.

even months beyond 28 days of curing [36]. Hence, there are periods later than 28 days that contribute to strength development. Three-day strength was not considered as early strength in this study because there was better demarcation in trends at 7 days of curing which was better from the point of view of analysis.

4.3.1. Percentage Strength Gain with Additive Quanta. The effect of BA on the development of strength of lime stabilized soil is presented in Figure 7. A brief glance easily reveals that the addition of BA results in a significant improvement in the immediate, early, and delayed strength of lime stabilized soil at all three lime contents. For 3\% lime stabilized soil, $0.25 \% \mathrm{BA}$ was found to be optimal dosage despite the fact that all BA additions produced positive strength gain. It produced a gain of $21.6 \%$ in immediate strength, $13.71 \%$ gain in early strength, and $23.7 \%$ gain in delayed strength. When $0.25 \%$ BA was added to $5.5 \%$ lime stabilized soil, it resulted in a $58.27 \%$ gain in immediate strength, $20.72 \%$ gain in early strength, and $32.72 \%$ gain in delayed strength. At $7 \%$ lime content for soil stabilization, $0.5 \%$ BA gave the maximum percentage gain in strength. At this dosage, the immediate, early, and delayed strength gains were $23.53 \%, 13.21 \%$ and $17.52 \%$, respectively. It should be noted that, at lower lime contents of $3 \%$ and $5.5 \%$, all BA contents gave positive strength gain, whereas at higher lime content of 7\%, higher BA contents of $1 \%$ and $2 \%$ resulted in a loss in strength. One obvious inference that can be seen when comparing the three different strengths, namely, immediate, early, and delayed strength of a particular lime dosage, the maximum effect is observed on immediate strength followed by delayed strength due to BA amendment. The least effect can be seen on the early strength. This is true, irrespective of lime content as the trends are similar across lime contents for all BA contents tested. Comparing the corresponding strength, not only delayed strength, in the cases of early as well as immediate strengths, BA seems to be effective at lower lime contents of LICL and ICL when compared to OLC. The maximum percentage gains are at ICL; however, the percentage gains of LICL are higher than OLC. When analyzing the work done by Hasan et al. [30], a similar trend was seen in which strength gain due to BA amendments of $4.5 \%$ lime was better than $6.5 \%$ lime stabilization. The strength increased from $750 \mathrm{kPa}$ to around $1000 \mathrm{kPa}$ when $4.5 \%$ lime was amended with $\mathrm{BA}$, while when $6.5 \%$ lime was amended with $\mathrm{BA}$, the strength increased from close to $950 \mathrm{kPa}$ to just above $1000 \mathrm{kPa}$. It is clear that $\mathrm{BA}$ amendment of lower lime content performed better when compared to higher lime content.

4.3.2. Percentage Strength Gain with Curing Period. The percentage strength improvement of BA admixed lime stabilized soil with curing period is presented in Figure 8. Percentage strength gain for subsequent curing periods involved the calculation of percentage difference in peak strengths for subsequent curing periods to understand the 


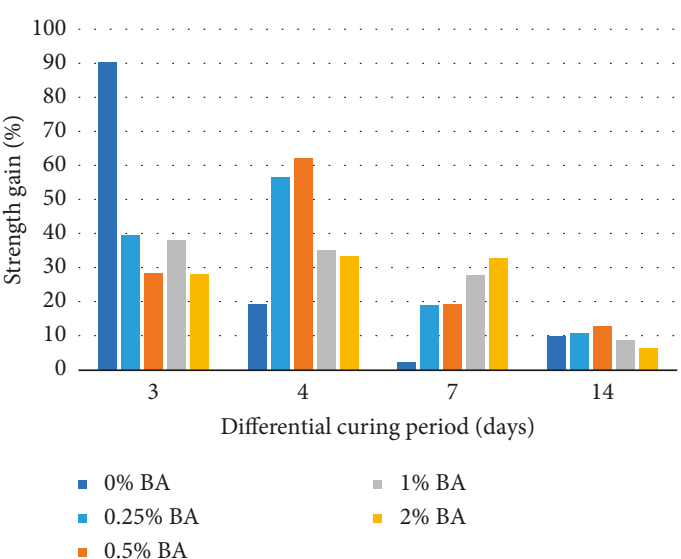

(a)

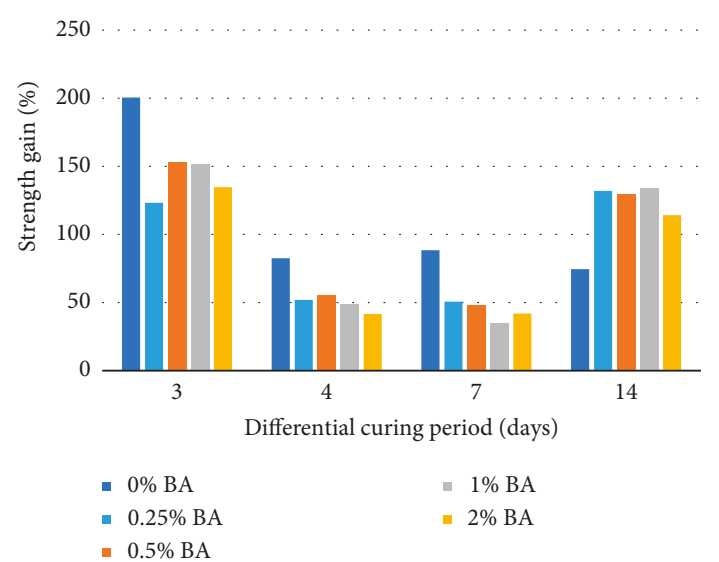

(b)

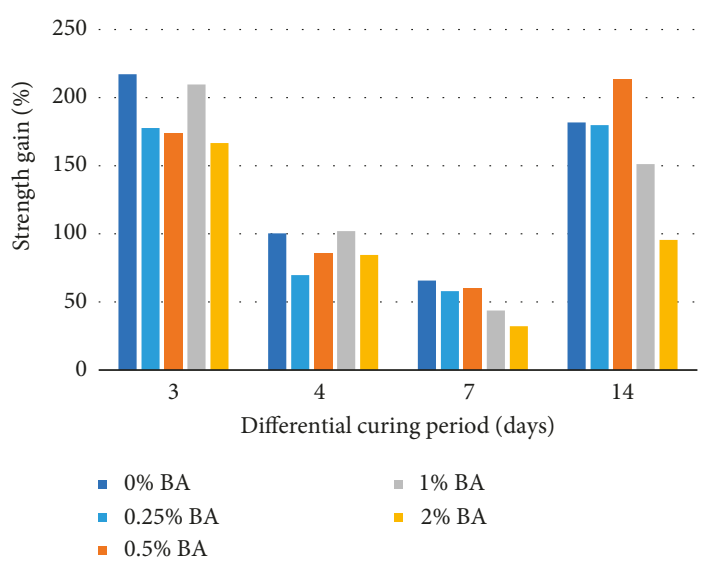

(c)

FIGURE 8: Percentage strength gain of (a) 3\%, (b) 5.5\%, and (c) 7\% lime stabilized soil with curing period.

stages of strength gain for different combinations. For this analysis, all curing periods adopted in the study were considered for the calculation of strength gain to understand strength development. A similar percentage strength gain analysis was earlier done for subsequent curing periods by Bhuvaneshwari et al. [36]. However, they had performed the analysis for only lime stabilized soil composites. But the trends exhibited by lime stabilized soil with a very high strength gain at 3 days, followed by strength gain reducing till 21 days of curing and again increasing at 28 days, were also similar to the ones exhibited in the present study. It is revealed that, with the exception of $3 \%$ lime stabilized soil admixed with BA, the percentage gain in strength is similar as in lime stabilization, that is, maximum gain within first three days. In the case of $3 \%$ lime stabilization, there was better percentage strength gain in the second stage of curing which may be due to the delayed onset of pozzolanic reactions between lime and BA at lower lime content as indicated. At higher lime content of $5.5 \%$ and $7 \%$, it can be seen that availability of lime for pozzolanic reactions at stage four of curing results in a significant percentage of the strength gained after 14 days of curing. Early strength has been an important part of studies carried out by several researchers [68-75] with a few studying it exclusively $[68,73-75]$.
Early strength development gains prominence in highway works where the need for quick opening of the road for traffic is of paramount importance. Several industrial wastes provide a good solution for enhancing the early strength of the stabilized soil due to the early formation of reaction products resulting in quick strength. In some cases, addition of industrial wastes to lime results in positive early strength development but also results in poor late strength performance [76]. Even chemical additives have been attempted for accelerating pozzolanic reactions for early strength gain [77]. Hence, the need to analyze not only early strength but late strength as well arises for adoption of industrial wastes as additives in soil stabilization. This study confines itself to the utilization of an industrial waste, BA, for improving the early as well as delayed strength of stabilized soil and has tried to analyze the positive effects on the same due to addition of BA.

4.4. Mineralogy of BA Amended Lime Stabilized Soil. The XRD scatter pattern can give a clear indication of the presence of crystalline and amorphous phases. Crystalline phases induce sharper peaks, whereas amorphous phases result in the formation of a broad hump. Figure 9 reveals the mineralogy of $7 \%$ lime stabilized soil amended with $0.5 \%$ 


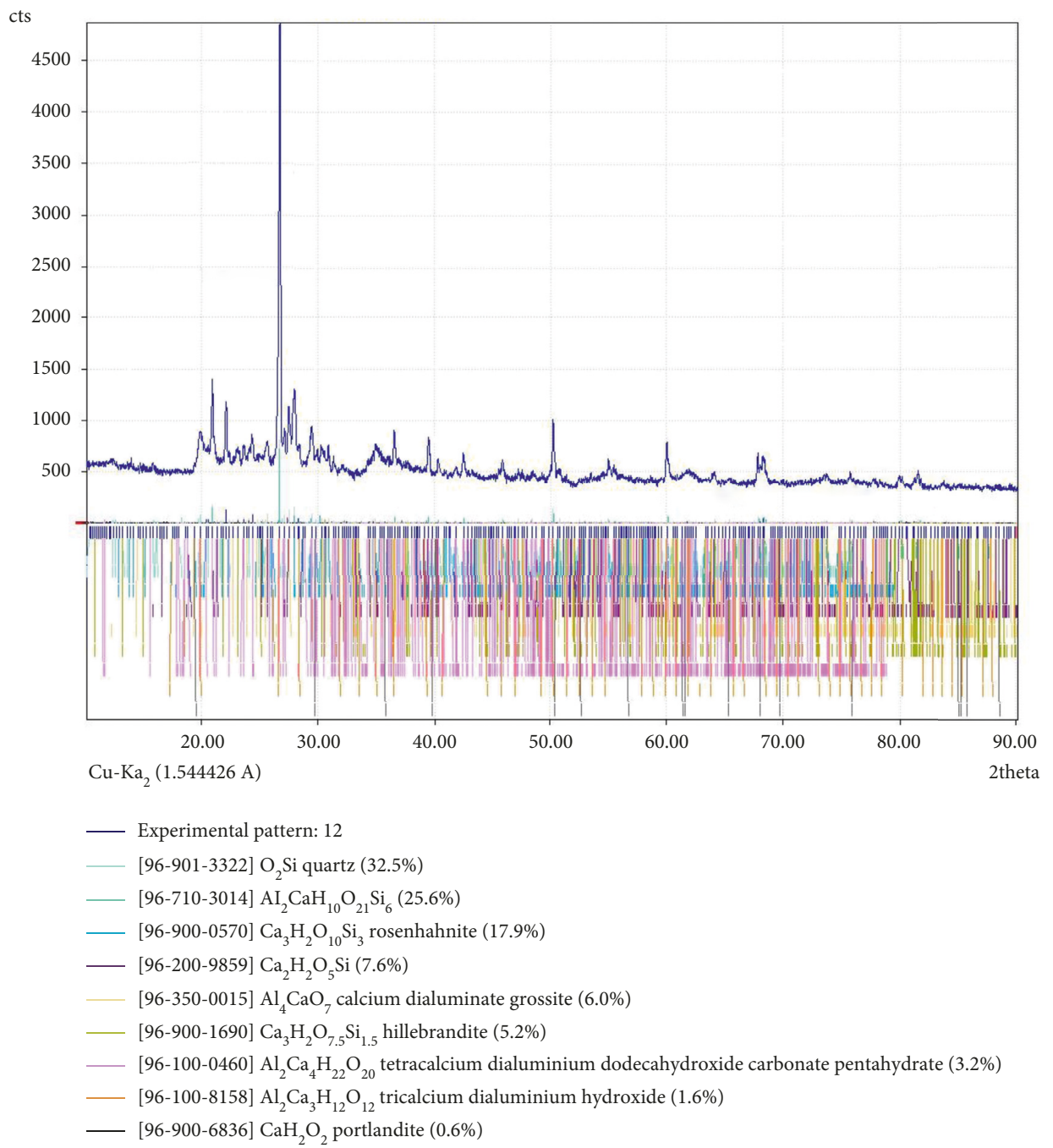

Figure 9: X-ray diffractogram of $7 \%$ lime stabilized soil with $0.5 \%$ BA.

BA. In the present case, it can be seen that the diffraction peaks are clear and sharp with little or no formation of the broad hump which is indicative of the presence of crystalline phases predominantly. The intensity of quartz at 2-theta of $26.68^{\circ}$ reduced from the original 16904 counts in soil to 4854 counts when $7 \%$ lime with $0.5 \%$ BA was used to stabilize the soil. The stabilization reaction does not cause a complete disappearance of existing peaks of mineral phases but rather a reduction in intensity of the peaks, specifically the quartz peak. Bhuvaneshwari et al. [36] also reported a similar behaviour in the case of lime treated soil composite. This clearly indicates the destruction of crystal structure due to dissolution of silica and alumina in the high $\mathrm{pH}$ environment during stabilization. The intensity of montmorillonite peak at 2 -theta values of $19.78^{\circ}$ and $28.02^{\circ}$ reduced from 2082 and 4825 to 941 and 813 counts, respectively, for $7 \%$ lime stabilization. When it was amended with $0.5 \% \mathrm{BA}$, the respective montmorillonite peaks dropped to 893 and 748 counts. This is an indication of efficacy of BA in hastening the stabilization process by faster breaking up of crystal structure and formation of reaction products resulting in suppression of peaks of native phases in the XRD scatter. This is in agreement with the statement of Hasan et al. [30] alluding to BA as an accelerator of pozzolanic reactions in lime stabilization. Moreover, pozzolanic reactions resulted in the formation of new reaction products whose peaks are identified in the phase identification process. Martirena Hernandez et al. [78] report the formation of $\mathrm{CSH}$, calcite, and portlandite along with quartz in hydrated pastes of lime-BA binders. AlavézRamírez et al. [6] also reported formation of $\mathrm{CAH}, \mathrm{CSH}$ minerals, and portlandite in the stabilization of earth blocks with lime and BA along with peaks of quartz. Several others have also attributed the formation of $\mathrm{CSH}$ to be responsible for increase in strength of the soil $[6,27,64,65]$. The mineralogy of the stabilized soil was analysed using Crystal Impact Match! Software Version 3.0.3 with Crystallography Open Database for reference patterns. The scatter pattern indicates the formation of minerals like rosenhahnite, $\alpha-\mathrm{C}_{2} \mathrm{SH}$, and hillebrandite and tricalcium dialuminium hydroxide and tetracalcium dialuminium pentahydrate. These minerals belong to the family of CSH and CAH minerals. Rosenhahnite, $\alpha-\mathrm{C}_{2} \mathrm{SH}$, and hillebrandite belong to the wollastonite group of $\mathrm{CSH}$ 
minerals [79]. Tricalcium dialuminium hydroxide and tetracalcium dialuminium pentahydrate are hydrates of calcium and alumina or $\mathrm{CAH}$ minerals. The formation and deposition of $\mathrm{CSH}$ and $\mathrm{CAH}$ minerals result in the cementation of the stabilized soil composite resulting in strength gain. A small proportion of portlandite was also detected. Portlandite contributes slightly to the strength as it reduces pore volume by converting some of the liquid water into solid form [80]. Calcite formation, however, was not detected which indicates that carbonation of lime has not taken place [36].

4.5. Microstructural Study. A microstructural study was performed to understand the changes taking place in the microstructure of stabilized soil due to the stabilization products. Figure 10 reveals the comparison of the microstructure of lime stabilized soil admixed with optimal dosage of BA. The micrographs reveal the changes in the microstructure of the soil due to addition of lime and BA to the soil. The platy structures are no longer clearly visible in the stabilized soil sample. This is due to the destruction of their structure due to dissolution and recombination during pozzolanic reactions. Wang et al. [81] revealed through SEM micrographs the destruction of flyash structure during stabilization of soil with lime and flyash. It can be seen that when $3 \%$ lime is added to the soil, there are portions of unreacted soil as $3 \%$ lime is not enough for modification of the soil properties. When $0.25 \% \mathrm{BA}$ is added to the stabilized soil, the microstructure looks different due to enhanced pozzolanic reactions in the presence of BA. There appears to be more foil like leafy formations indicating a better progress in pozzolanic reactions and cementitious connectors that result in better aggregation of soil particles. Bhuvaneshwari et al. [36] also reported similar formations in the microstructure of lime stabilized soil. The zones of unreacted soil have also reduced and are barely noticeable.

In the case of $5.5 \%$ and $7 \%$ lime stabilized soil, there is a more even matrix of the stabilized soil with a denser microstructure in comparison with 3\%. Presence of unreacted soil zones is not seen, indicating a better reaction between soil and lime. The microstructure reveals a more even cementation rather than cementitious connectors, indicating a further progress in pozzolanic reaction and deposition of reaction products. BA amended 5.5\% and 7\% lime stabilized soil specimens show a more even, compact, and denser matrix when compared to pure lime stabilized soil. They show welldeveloped floccules due to the cementations. Sante et al. [82] and Bhuvaneshwari et al. [83] also reported development of such floccules in the case of lime treated clayey soil and limeflyash treated dispersive clay, respectively. The voids in the BA amended soil matrix are also less distinct when compared to pure lime stabilization, indicating a better aggregation of the soil during stabilization reaction resulting in higher strength. Muhmed and Wanatowski [84] attributed the presence of such voids devoid of cementing products in the microstructure for a reduced UCS of lime stabilized kaolinite. Jamsawang et al. [31] attributed the filling of pore spaces due to cementitious compounds which enhance the intercluster bonding resulting in strength gain.

\section{Conclusion}

The study involved the investigation of the effect of addition of BA to lime stabilization of an expansive soil. Three different lime contents were selected by determining lime contents scientifically required for modifying and stabilizing soil based on established procedures. These lime contents were amended with four different BA contents to study the effect of amendment on lime stabilization. The results of the study shed light on the following important revelations:

(i) For the soil under investigation, the minimum lime content required for modifying soil properties was found to be $5.5 \%$ and optimum lime content for stabilizing the soil was found to be $7 \%$. These two lime contents divide the relationship between lime content and strength development into three stages. Based on this, $3 \%, 5.5 \%$, and $7 \%$ lime contents were selected for investigation to understand BA amendment in different stages of lime stabilization. BA amendment of the three lime contents revealed that it was capable of further enhancing the strength of lime stabilized soil irrespective of lime content adopted for stabilization. Thus, BA amendment of lime stabilization works for any stage of lime stabilization.

(ii) Curing plays an important role in development of strength of BA amended lime stabilized soil. Curing influences strength development irrespective of lime content adopted for stabilization. Provision of curing results in a significant gain in strength of the stabilized soil. Addition of BA resulted in significant increase in immediate strength for all three lime contents in the range of $24 \%$ to $58 \%$. The amendment also resulted in a $13 \%$ to $21 \%$ increase in the early strength and a $18 \%$ to $33 \%$ increase in the delayed strength. Thus, BA amendment results in immediate initiation of pozzolanic reactions, resulting in strength gain at 2 hours of curing. BA amendment of lime stabilization is also capable of sustaining enhanced rate of pozzolanic reactions over extended curing periods, resulting in strength enhancement across different curing periods investigated. ICL content with optimal BA can produce almost the same strength as OLC without BA. Hence, addition of BA to lime stabilized soil is capable of developing similar strength at lower lime content than without BA at higher lime content when sufficient curing is provided. It can be stated that $B A$ amended lime stabilized soil develops strength quicker when compared to pure lime stabilization, resulting in higher strength at similar curing periods.

(iii) The optimal dosage of BA for developing maximum strength of lime stabilized soil was between $0.25 \%$ and $0.5 \%$ for the soil under investigation for all three lime contents. The BA required for higher strength development remained static below ICL but increased when lime content went above ICL. This indicated that when sufficient lime was available 


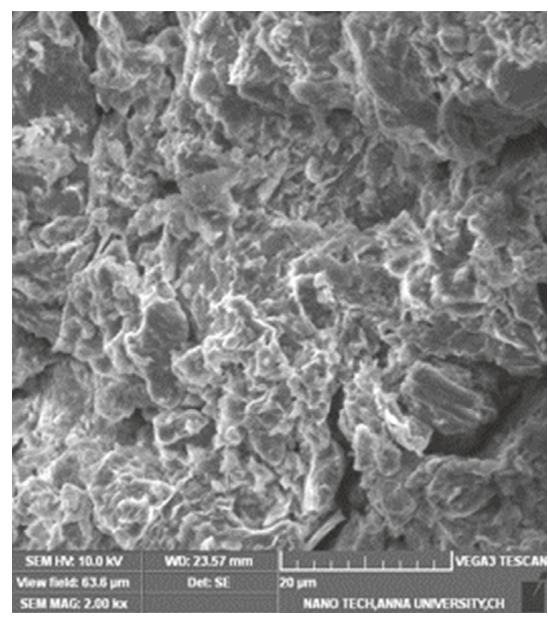

(a)

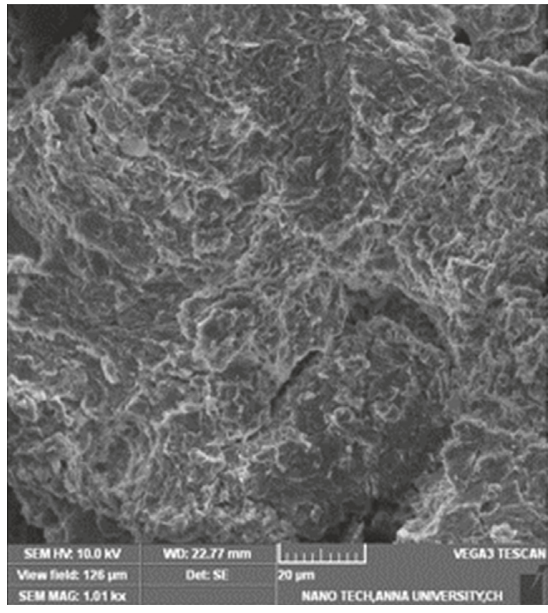

(c)

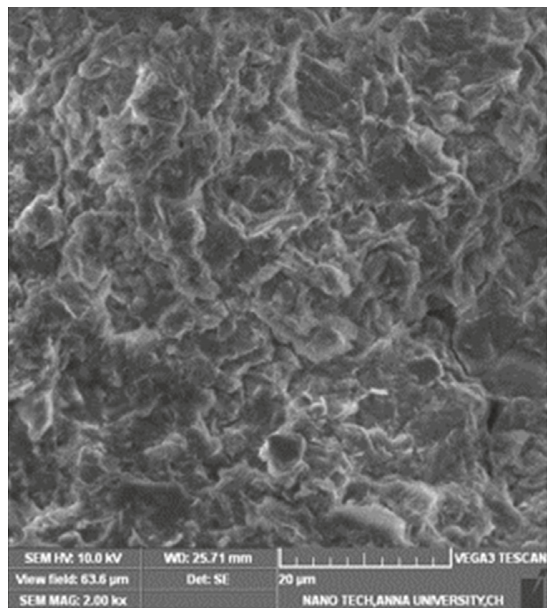

(e)

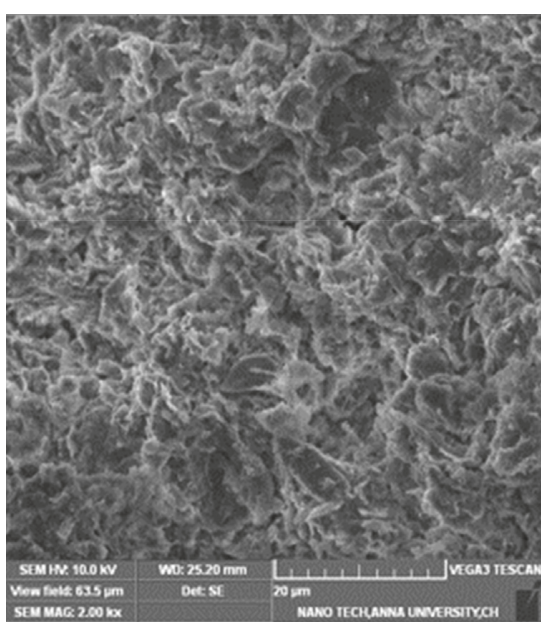

(b)

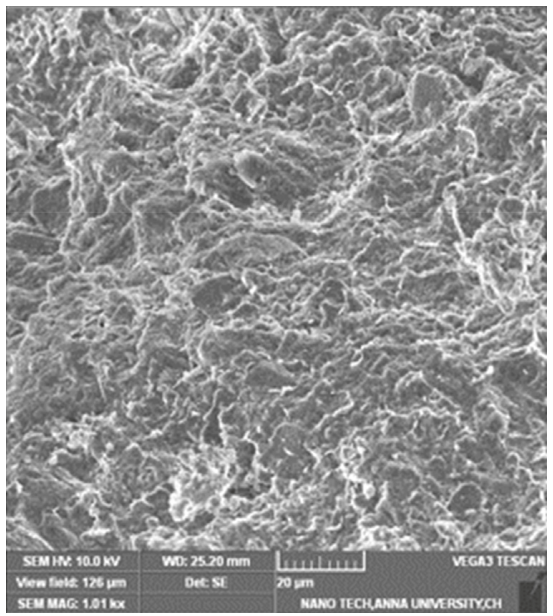

(d)

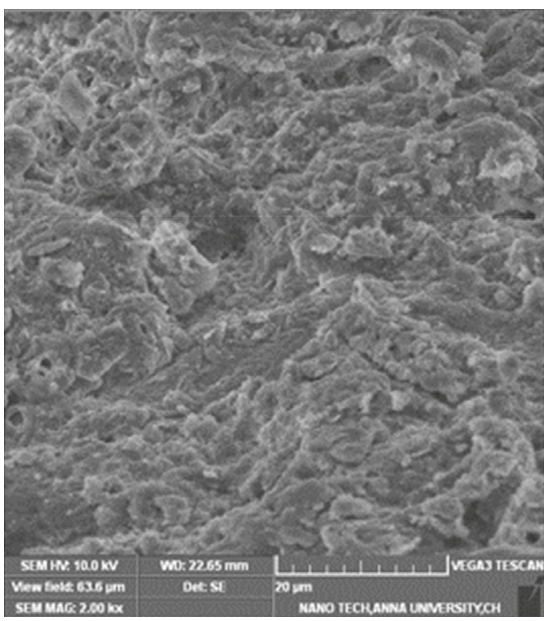

(f)

Figure 10: SEM micrographs of lime stabilized soil: (a) soil + 3\% lime; (b) soil + 3\% lime $+0.25 \%$ BA; (c) soil + 5.5\% lime; (d) soil + 5.5\% lime $+0.25 \%$ BA; (e) soil $+7 \%$ lime; (f) soil $+7 \%$ lime $+0.5 \%$ BA.

for stabilization, more BA got involved in the stabilization reaction resulting in higher BA requirement for developing maximum strength. However, the effectiveness of BA in enhancing the strength of lime stabilized soil is better when lime content is up to ICL as indicated by the percentage strength gains. The 
maximum strength gain on addition of BA was achieved not at OLC but at ICL.

(iv) The percentage strength gains of all three lime contents admixed with BA showed a similar pattern with relatively higher immediate strength gain, lower early strength gain, and moderate delayed strength gain. This may be indicative of a relative slowdown in the pozzolanic activity of the combination during the early stages of curing which slowly increases with prolonged curing. Percentage strength gain with curing indicated that the maximum strength gain was achieved within the first three days of curing. However, at higher lime content, the percentage strength gain at later stages of curing was comparable to that of early strength gain due to the availability of sufficient lime for pozzolanic reactions to proceed. The patterns of percentage strength gain were similar for pure lime stabilization as well as BA amended lime stabilization of expansive soil.

(v) Mineralogical investigation on OLC stabilized soil amended with $0.5 \% \mathrm{BA}$ indicated reduction in peaks of quartz and montmorillonite and development of new peaks corresponding to reaction products of pozzolanic reactions. The reduction in peaks is a clear indication of destruction of the crystal structure and its use in pozzolanic reactions resulting in the formation of $\mathrm{CSH}$ and $\mathrm{CAH}$ minerals responsible for increase in strength. Addition of BA resulted in much better utilization of quartz present in the soil in the lime-soil reactions, leading to a reduced quartz proportion and increased strength. Addition of BA to lime produces an even and dense matrix of stabilized soil similar to that of pure lime stabilized soil.

Thus, BA can be used as an effective additive for augmenting the immediate, early, and delayed strength of lime stabilized soil. The overall picture indicates that $0.5 \% \mathrm{BA}$ or lesser is enough to produce optimal improvements to the strength of the stabilized soil.

\section{Abbreviations}

ASTM: American Society for Testing and Materials

BA: Bagasse ash

BIS: $\quad$ Bureau of Indian standards

CAH: Calcium aluminate hydrate

$\mathrm{CH}$ : High plastic clay

$\mathrm{CSH}$ : Calcium silicate hydrate

FSI: $\quad$ Free swell index

$G_{s}: \quad$ Specific gravity of solids

ICL: Initial consumption of lime

$I_{\mathrm{P}}$ : $\quad$ Plasticity index

LICL: Less than ICL

OLC: Optimum lime content

PG: Phosphogypsum

SEM: Scanning electron microscopy

TRRL: Transport and Road Research Laboratory

UCS: Unconfined compression strength

$w_{\mathrm{L}}$ : Liquid limit $w_{\text {opt }}: \quad$ Optimum moisture content

$w_{\mathrm{P}}$ : $\quad$ Plastic limit

$w_{\mathrm{S}}: \quad$ Shrinkage limit

XRD: X-ray diffraction

XRF: X-ray fluorescence

$\gamma_{\text {dmax }}$ : Maximum dry density.

\section{Conflicts of Interest}

The authors declare that there are no conflicts of interest regarding the publication of this paper.

\section{Acknowledgments}

The authors are indebted to the management of Tagore Engineering College for providing the laboratory facilities to carry out this research work. The authors would also like to acknowledge the XRF facility provided by SAIF, IITBombay, Mumbai, and XRD and SEM facility provided by CNST, Anna University, Chennai. The authors would also like to thank Mr. M. Sasi Kumar, Lab Instructor, Soil Engineering Laboratory, and students of B.E. Civil Engineering for helping out with the laboratory testing work. Last but not least, the authors would like to record their special thanks to Dr. S. Vidhya Lakshmi, Ph.D. (Swansea University, UK), for painstakingly proofreading the paper to improve its quality.

\section{References}

[1] S. Wild, J. M. Kinuthia, G. I. Jones, and D. D. Higgins, "Effects of partial substitution of lime with ground granulated blast furnace slag (GGBS) on the strength properties of limestabilised sulphate-bearing clay soils," Engineering Geology, vol. 51, no. 1, pp. 37-53, 1998.

[2] Z. Ji-ru and C. Xing, "Stabilization of expansive soil by lime and fly ash," Journal of Wuhan University of TechnologyMaterials Science Edition, vol. 17, no. 4, pp. 73-77, 2002.

[3] J. N. Jha and K. S. Gill, "Effect of rice husk ash on lime stabilization," Journal of The Institution of Engineers, vol. 87, pp. 33-39, 2006.

[4] R. S. Sharma, B. R. Phanikumar, and V. B. Rao, "Engineering behavior of a remolded expansive clay blended with lime, calcium chloride, and rice-husk ash," Journal of Materials in Civil Engineering, vol. 20, no. 8, pp. 509-515, 2008.

[5] A. J. Choobbasti, H. Ghodrat, M. J. Vahdatirad et al., "Influence of using rice husk ash in soil stabilization method with lime," Frontiers of Earth Science in China, vol. 4, no. 4, pp. 471-480, 2010.

[6] R. Alavéz-Ramírez, P. Montes-García, J. Martínez-Reyes, D. C. Altamirano-Juárez, and Y. Gochi-Ponce, "The use of sugarcane bagasse ash and lime to improve the durability and mechanical properties of compacted soil blocks," Construction and Building Materials, vol. 34, pp. 296-305, 2012.

[7] E. Celik and Z. Nalbantoglu, "Effects of ground granulated blastfurnace slag (GGBS) on the swelling properties of limestabilized sulfate-bearing soils," Engineering Geology, vol. 163, pp. 20-25, 2013.

[8] A. T. Manikandan and M. Moganraj, "Consolidation and rebound characteristics of expansive soil by using lime and bagasse ash," International Journal of Research in Engineering and Technology, vol. 3, no. 4, pp. 403-411, 2014. 
[9] M. Balakrishnan and V. S. Batra, "Valorization of solid waste in sugar factories with possible applications in India: a review," Journal of Environmental Management, vol. 92, no. 11, pp. 2886-2891, 2011.

[10] A. Sales and S. A. Lima, "Use of Brazilian sugarcane bagasse ash in concrete as sand replacement," Waste Management, vol. 30, no. 6, pp. 1114-1122, 2010.

[11] G. Sua-iam and N. Makul, "Use of increasing amounts of bagasse ash waste to produce self-compacting concrete by adding limestone powder waste," Journal of Cleaner Production, vol. 57, pp. 308-319, 2013.

[12] S. A. Lima, H. Varum, A. Sales, and V. F. Neto, "Analysis of the mechanical properties of compressed earth block masonry using the sugarcane bagasse ash," Construction and Building Materials, vol. 35, pp. 829-837, 2012.

[13] J. James, P. K. Pandian, K. Deepika, J. M. Venkatesh, V. Manikandan, and P. Manikumaran, "Cement stabilized soil blocks admixed with sugarcane bagasse ash," Journal of Engineering, vol. 2016, Article ID 7940239, 9 pages, 2016.

[14] J. James and P. K. Pandian, "Valorisation of sugarcane bagasse ash in manufacture of lime-stabilized blocks," Slovak Journal of Civil Engineering, vol. 24, no. 2, pp. 7-15, 2016.

[15] D. Tonnayopas, "Green building bricks made with clays and sugar cane bagasse ash," in Proceedings of the 11th International Conference on Mining, Materials and Petroleum Engineering, pp. 7-14, Chiang Mai, Thailand, November 2013.

[16] A. E. Souza, S. R. Teixeira, G. T. A. Santos, F. B. Costa, and E. Longo, "Reuse of sugarcane bagasse ash (SCBA) to produce ceramic materials," Journal of Environmental Management, vol. 92, no. 10, pp. 2774-2780, 2011.

[17] J. James and P. K. Pandian, "A short review on the valorisation of sugarcane bagasse ash in the manufacture of stabilized/sintered earth blocks and tiles," Advances in $\mathrm{Ma}$ terials Science and Engineering, vol. 2017, Article ID 1706893, 15 pages, 2017.

[18] M. A. Muazu, "Evaluation of plasticity and particle size distribution characteristics of bagasse ash on cement treated lateritic soil," Leonardo Journal of Sciences, vol. 10, no. 1, pp. 137-152, 2007.

[19] M. A. Muazu, "Influence of compactive effort on bagasse ash with cement treated lateritic soil," Leonardo Electronic Journal of Practices and Technologies, vol. 10, no. 1, pp. 79-92, 2007.

[20] M. Chittaranjan, M. Vijay, and D. Keerthi, "Agricultural wastes as soil stabilizers," International Journal of Earth Sciences and Engineering, vol. 4, no. 6, pp. 50-51, 2011.

[21] K. C. Onyelowe, "Cement stabilized akwuete lateritic soil and the use of bagasse ash as admixture," International Journal of Earth Sciences and Engineering, vol. 1, no. 2, pp. 16-20, 2012.

[22] A. K. Sabat, "Utilization of bagasse ash and lime sludge for construction of flexible pavements in expansive soil areas," Electronic Journal of Geotechnical Engineering, vol. 17, pp. 1037-1046, 2012.

[23] K. J. Osinubi, A. O. Eberemu, and A. A. Amadi, "Compatibility of compacted lateritic soil treated with bagasse ash and municipal solid waste leachate," International Journal of Environment and Waste Management, vol. 10, no. 4, pp. 365-376, 2012.

[24] K. G. Osinube and S. A. Thomas, "Influence of compactive efforts on bagasse ash treated black cotton soil," World Academy of Science, Engineering and Technology, vol. 7, no. 1, pp. 1541-1548, 2013.

[25] R. Ali, H. Khan, and A. A. Shah, "Expansive soil stabilization using marble dust and bagasse ash," International Journal of Scientific Research, vol. 3, no. 6, pp. 2812-2816, 2014.
[26] K. J. Osinubi, T. S. Ijimdiya, and I. Nmadu, "Lime stabilization of black cotton soil using bagasse ash as admixture," Advanced Materials Research, vol. 62, pp. 3-10, 2009.

[27] J. A. Sadeeq, J. Ochepo, A. B. Salahuddin, and S. T. Tijjani, "Effect of bagasse ash on lime stabilized lateritic soil," Jordan Journal of Civil Engineering, vol. 9, no. 2, pp. 203-213, 2015.

[28] L. C. Dang, H. Hasan, B. Fatahi, R. Jones, and H. Khabbaz, "Enhancing the engineering properties of expansive soil using bagasse ash and hydrated lime," International Journal of Geomate, vol. 11, no. 25, pp. 2447-2454, 2016.

[29] L. C. Dang, H. Hasan, B. Fatahi, and H. Khabbaz, "Influence of strength and mechanical behaviour of bagasse ash and hydrated lime stabilized expansive soil," in Proceedings of the GEOQuebec 2015-Challenges from North to South, Quebec city, QC, Canada, September 2015.

[30] H. Hasan, H. Khabbaz, and B. Fatahi, "Strength property of expansive soils treated with bagasse ash," Advances in Characterization and Analysis of Expansive Soils and Rocks, Sustainable Civil Infrastructures, L. R. Hoyos and J. McCartney, Eds., pp. 24-35, Springer International Publishing, Switzerland, 2017.

[31] P. Jamsawang, H. Poorahong, N. Yoobanpot, S. Songpiriyakij, and P. Jongpradist, "Improvement of soft clay with cement and bagasse ash waste," Construction and Building Materials, vol. 154, pp. 61-71, 2017.

[32] J. James and P. K. Pandian, "Industrial wastes as auxiliary additives to cement/lime stabilization of soils," Advances in Civil Engineering, vol. 2016, Article ID 1267391, 17 pages, 2016.

[33] G. W. Brindley, "Identification of clays mineraly by X-ray diffraction analysis," Clays and Clay Technology, vol. 169, no. 3, pp. 119-129, 1955.

[34] W. Harris and N. White, "X-ray diffraction techniques for soil mineral identification," Methods of Soil Analysis. Part 5. Mineralogical Methods, pp. 1-36, Soil Science Society of America, Fitchburg, WI, USA, 2007.

[35] E. Kalkan, "Impact of wetting-drying cycles on swelling behavior of clayey soils modified by silica fume," Applied Clay Science, vol. 52, no. 4, pp. 345-352, 2011.

[36] S. Bhuvaneshwari, R. G. Robinson, and S. R. Gandhi, "Behaviour of lime treated cured expansive soil composites," Indian Geotechnical Journal, vol. 44, no. 3, pp. 278-293, 2013.

[37] S. K. Dash and M. Hussain, "Lime stabilization of soils: reappraisal," Journal of Materials in Civil Engineering, vol. 24, no. 6, pp. 707-714, 2011.

[38] A. Kampala and S. Horpibulsuk, "Engineering properties of silty clay stabilized with calcium carbide residue," Journal of Materials in Civil Engineering, vol. 25, no. 5, pp. 632-644, 2013.

[39] P. Solanki and M. Zaman, "Microstructural and mineralogical characterization of clay stabilized using calcium-based stabilizers," Scanning Electron Microscopy, V. Kazmiruk, Ed., pp. 771-798, Intech Open, United Kingdom, 2012.

[40] J. Torres Agredo, R. M. de Gutiérrez, C. E. Escandón Giraldo, and L. O. González Salcedo, "Characterization of sugar cane bagasse ash as supplementary material for Portland cement," Ingeniería e Investigación, vol. 34, no. 1, pp. 5-10, 2014.

[41] M. A. S. Schettino and J. N. F. Holanda, "Characterization of sugarcane bagasse ash waste for its use in ceramic floor tile," Procedia Materials Science, vol. 8, pp. 190-196, 2015.

[42] J. M. Rodriguez-Diaz, J. O. P. Garcia, L. R. B. Sanchez et al., "Comprehensive characterization of sugarcane bagasse ash for its use as an adsorbent," BioEnergy Research, vol. 8, no. 4, pp. 1885-1895, 2015. 
[43] A. Bahurudeen, K. Wani, M. A. Basit, and M. Santhanam, "Assesment of pozzolanic performance of sugarcane bagasse ash," Journal of Materials in Civil Engineering, vol. 28, no. 2, p. 4015095, 2015.

[44] K. C. P. Faria, R. F. Gurgel, and J. N. F. Holanda, "Recycling of sugarcane bagasse ash waste in the production of clay bricks," Journal of Environmental Management, vol. 101, pp. 7-12, 2012.

[45] BIS, IS 2720 Methods of Test for Soils: Part 5 Determination of Liquid and Plastic Limit, BIS, India, 1985.

[46] BIS, IS 2720 Methods of Test for Soils: Part 6 Determination of Shrinkage Factors, BIS, India, 1972.

[47] BIS, IS 2720 Methods of Test for Soils Part 3: Determination of Specific Gravity/Section 1 Fine Grained Soils, BIS, India, 1980.

[48] BIS, IS 2720 Methods of Test for Soils: Part 4 Grain Size Analysis, BIS, India, 1985.

[49] BIS, IS 2720 Methods of Test for Soils: Part 7 Determination of Water Content-Dry Density Relation Using Light Compaction, BIS, India, 1980.

[50] BIS, IS 2720 Methods of Test for Soils: Part 10-Determination of Unconfined Compressive Strength, BIS, India, 1991.

[51] BIS, IS 2720 Methods of Test for Soils: Part 26 Determination of pH, BIS, India, 1987.

[52] BIS, IS 1498 Classification and Identification of Soils for General Engineering Purposes, BIS, India, 1970.

[53] A. A. Nasrizar, K. Ilamparuthi, and M. Muttharam, "Quantitative models for strength of lime treated expansive soil," in Proceedings of the GeoCongress 2012, pp. 978-987, American Society of Civil Engineers, Oakland, CA, USA, March 2012.

[54] ASTM, D6276 Standard Test Method for using pH to Estimate the Soil-Lime Proportion Requirement, ASTM, West Conshohocken, PA, USA, 2006.

[55] M. R. Thompson, "Factors influencing the plasticity and strength of lime soil mixtures," University of Illinois, vol. 64, no. 100 , pp. 1-20, 1967.

[56] P. V. Sivapullaiah, B. Katageri, and R. N. Herkal, "Enhancement of strength of soft soils with fly ash and lime," in Proceedings of First Sri Lankan Geotechnical Society International Conference on Soil and Rock Engineering, pp. 1-6, Colombo, Sri Lanka, August 2007.

[57] D. Ciancio, C. T. S. Beckett, and J. A. H. Carraro, "Optimum lime content identification for lime-stabilised rammed earth," Construction and Building Materials, vol. 53, pp. 59-65, 2014.

[58] J. James and P. K. Pandian, "Effect of phosphogypsum on the strength of lime stabilized expansive soil," Gradevinar, vol. 66, no. 12, pp. 1109-1116, 2014.

[59] A. Singh and B. C. Punmia, "A new laboratory compaction device and its comparison with the proctor test," Highway Research News, vol. 17, pp. 37-41, 1965.

[60] BIS, IS 4332 Methods of Test for Stabilized Soils: Part 3 Test for Determination of Moisture Density Relations for Stabilized Soil Mixtures, BIS, India, 1967.

[61] Y. Bagheri, F. Ahmad, and M. A. M. Ismail, "Strength and mechanical behavior of soil-cement-lime-rice husk ash (soil-CLR) mixture," Materials and Structures, vol. 47, no. 12, pp. 55-66, 2014.

[62] BIS, IS 4332 Methods of Test for Stabilized Soils: Part 5 Determination of Unconfined Compressive Strength of Stabilized Soils, BIS, India, 1970.

[63] Z. Metelková, J. Boháč, R. Přikryl, and I. Sedlářová, "Maturation of loess treated with variable lime admixture: pore space textural evolution and related phase changes," Applied Clay Science, vol. 61, pp. 37-43, 2012.
[64] M. Wubshet, Bagasse Ash as a Sub-Grade Soil Stabilizing Material, Addis Ababa Institute of Technology, Addis Ababa, Ethiopia, 2013.

[65] M. Wubshet and S. Tadesse, "Stabilization of expansive soil using bagasse ash and lime," Journal of the European Economic Association, vol. 32, pp. 21-26, 2014.

[66] V. Greepala and R. Parichartpreecha, "Effects of using flyash, rice husk ash and bagasse ash as replacement materials on the compressive strength and water absorption of lateritic soilcement interlocking blocks," in Proceedings of 9th Australasian Masonry Conference, pp. 583-603, Queenstown, New Zealand, February 2011.

[67] M. Al-Mukhtar, A. Lasledj, and J.-F. Alcover, "Behaviour and mineralogy changes in lime-treated expansive soil at $20^{\circ} \mathrm{C}$," Applied Clay Science, vol. 50, no. 2, pp. 191-198, 2010.

[68] J. James and P. K. Pandian, "A study on the early ucc strength of stabilized soil admixed with industrial waste materials," International Journal of Earth Sciences and Engineering, vol. 7, no. 3, pp. 1055-1063, 2014.

[69] M. Tao and Z. Zhang, "Enhanced performance of stabilized by-product gypsum," Journal of Materials in Civil Engineering, vol. 17, no. 6, pp. 617-623, 2005.

[70] Y. Xizhong, L. Shudong, and C. Wei, "Silt subgrade modification and stabilization with ground granulated blast furnace slag and carbide lime in areas with a recurring high groundwater," in Proceedings of International Conference on Mechanic Automation and Control Engineering, IEEE, pp. 2063-2067, Wuhan, China, June 2010.

[71] P. V. Sivapullaiah and A. K. Jha, "Gypsum induced strength behaviour of fly ash-lime stabilized expansive soil," Geotechnical and Geological Engineering, vol. 32, no. 5, pp. 1261-1273, 2014.

[72] S. M. Al-zaidyeen and A. N. S. Al-qadi, "Effect of phosphogypsum as a waste material in soil stabilization of pavement layers," Jordan Journal of Civil Engineering, vol. 9, no. 1, pp. 1-7, 2015.

[73] W. Zhe, X. Si-fa, and W. Guo-cai, "Study of early strength and shrinkage properties of cement or lime solidified soil," Energy Procedia, vol. 16, pp. 302-306, 2012.

[74] J. James and P. K. Pandian, "Development of early strength of lime stabilized expansive soil: effect of red mud and egg shell ash," Acta Technica Corviniensis-Bulletin of Engineering, vol. 9, no. 1, pp. 93-100, 2016.

[75] J. James and P. K. Pandian, "Role of phosphogypsum and ceramic dust in amending the early strength development of a lime stabilized expansive soil," International Journal of Sustainable Construction Engineering and Technology, vol. 7, no. 2, pp. 38-49, 2016.

[76] S. Kumar, R. K. Dutta, and B. Mohanty, "Engineering properties of bentonite stabilized with lime and phosphogypsum," Slovak Journal of Civil Engineering, vol. 22, no. 4, pp. 35-44, 2014.

[77] J. Zengguo and Z. Yuan, "Mechanism and optimal application of chemical additives for accelerating early strength of limeflyash stabilized soils," Journal of Wuhan University of Technology-Materials Science Edition, vol. 20, no. 3, pp. 110112, 2005.

[78] J. Martirena Hernández, B. Middendorf, M. Gehrke, and H. Budelmann, "Use of wastes of the sugar industry as pozzolana in lime-pozzolana binders: study of the reaction," Cement and Concrete Research, vol. 28, no. 11, pp. 1525-1536, 1998.

[79] I. G. Richardson, “The calcium silicate hydrates," Cement and Concrete Research, vol. 38, no. 2, pp. 137-158, 2008. 
[80] J. Thomas and H. Jennings, "Calcium hydroxide (CH)," 2018, http://iti.northwestern.edu/cement/monograph/Monograph5_ 4_3.html.

[81] D. Wang, N. Edine, and R. Zentar, "Strength and deformation properties of Dunkirk marine sediments solidified with cement, lime and fly ash," Engineering Geology, vol. 166, pp. 90-99, 2013.

[82] M. D. Sante, E. Fratalocchi, F. Mazzieri, and E. Pasqualini, "Time of reactions in a lime treated clayey soil and influence of curing conditions on its microstructure and behaviour," Applied Clay Science, vol. 99, pp. 100-109, 2014.

[83] S. Bhuvaneshwari, B. Soundra, R. G. Robinson, and S. R. Gandhi, "Stabilization and microstructural modification of dispersive clayey soils," in Proceedings of the 1st International Conference on Soil and Rock Engineering, Srilankan Geotechnical Society, pp. 1-7, Columbo, Srilanka, August 2007.

[84] A. Muhmed and D. Wanatowski, "Effect of lime stabilisation on the strength and microstructure of clay," IOSR Journal of Mechanical and Civil Engineering, vol. 6, no. 3, pp. 87-94, 2013. 


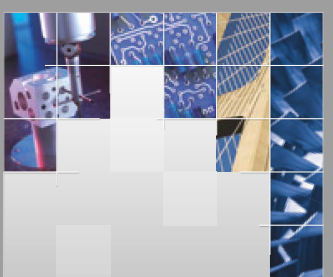

\section{Enfincering}
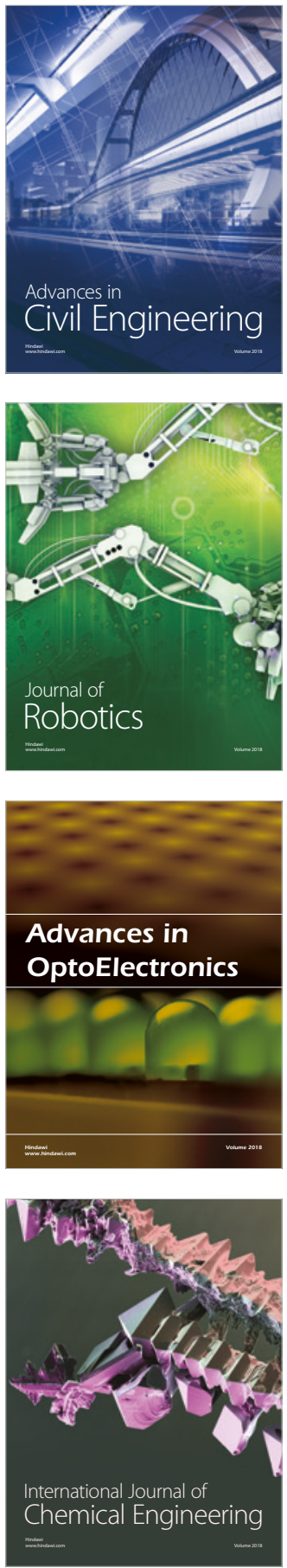

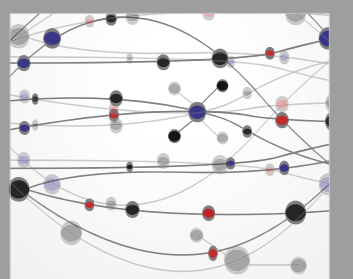

\section{Rotating \\ Machinery}

The Scientific World Journal

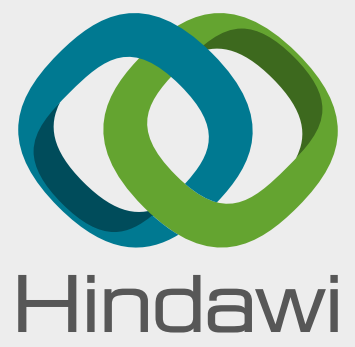

Submit your manuscripts at

www.hindawi.com
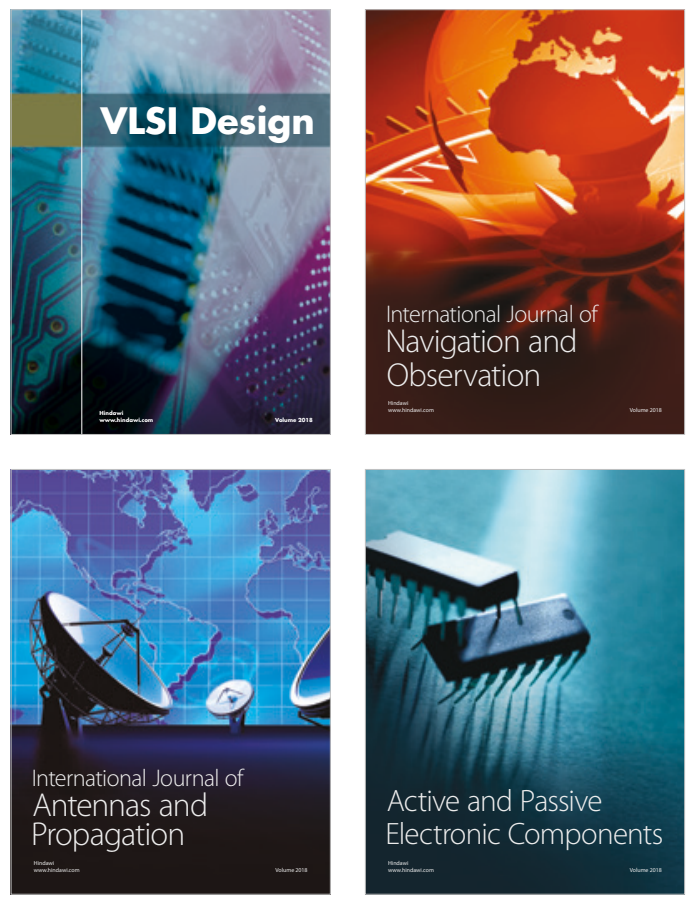
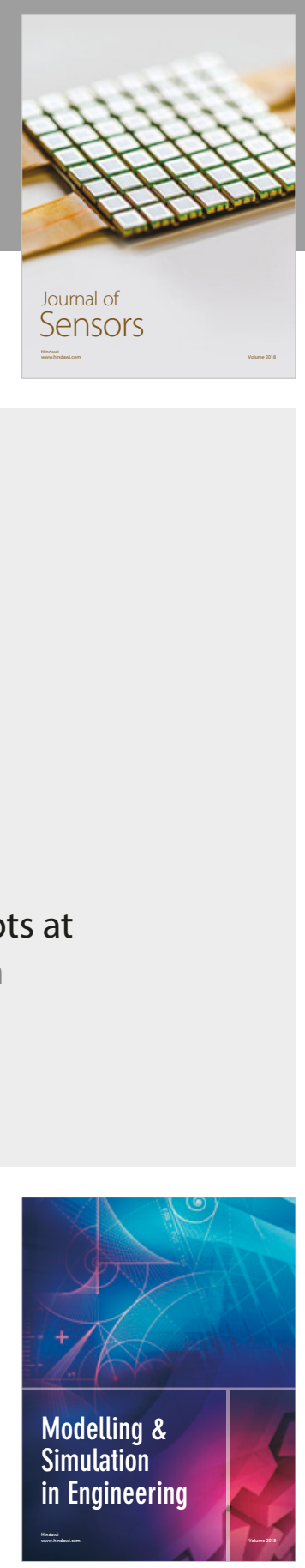

\section{Advances \\ Multimedia}
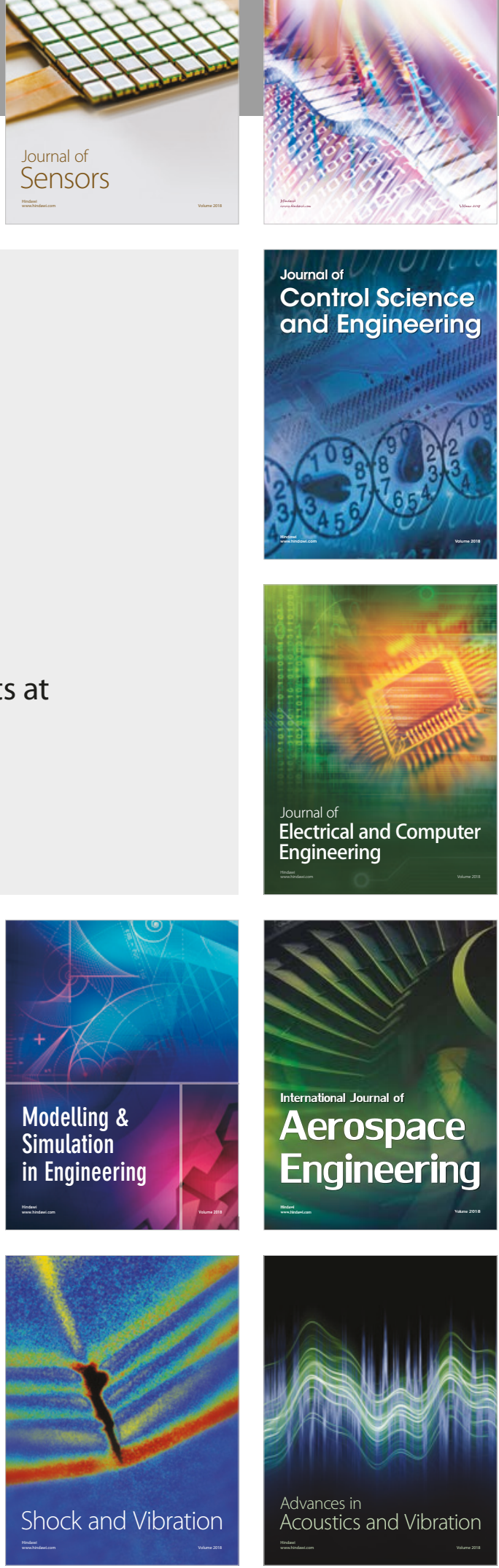